\title{
Spatial distribution of fifty ornamental fish species on coral reefs in the Red Sea and Gulf of Aden
}

\author{
Maroof A. Khalaf', Mohamed Abdallah² \\ I The University of Jordan, Department of Marine Biology, Faculty of Marine Sciences, P. O. Box 195, Aqaba, \\ Jordan 2 Fishery resources expert, Ministry of Environment, P. O. Box: 8703, Doha, State of Qatar \\ Corresponding author: Maroof A. Khalaf(m.khalaf@ju.edu.jo)
}

Academic editor: N. Bogutskaya | Received 6 May 2013 | Accepted 14 November 2013 | Published 6 January 2014

Citation: Khalaf MA, Abdallah M (2014) Spatial distribution of fifty ornamental fish species on coral reefs in the Red Sea and Gulf of Aden. ZooKeys 367: 33-64. doi: 10.3897/zookeys.367.5476

\begin{abstract}
The spatial distribution of 50 ornamental fish species from shallow water habitats on coral reefs were investigated using visual census techniques, between latitudes $11-29^{\circ} \mathrm{N}$ in the Red Sea, in Jordan, Egypt, Saudi Arabia, and Yemen, and in the adjacent Gulf of Aden in Djibouti. One hundred eighteen transects (each $100 \times 5 \mathrm{~m}$ ) were examined in 29 sites (3-8 sites per country). A total of 522,523 fish individuals were counted during this survey, with mean abundance of $4428.2 \pm 87.26$ individual per $500 \mathrm{~m}^{2}$ transect. In terms of relative abundance (RA), the most abundant species were Blue green damselfish, Chromis viridis (RA=54.4\%), followed by Sea goldie, Pseudanthias squamipinnis ( $\mathrm{RA}=34.7)$, Whitetail dascyllus, Dascyllus aruanus $(\mathrm{RA}=2.6 \%)$, Marginate dascyllus, Dascyllus marginatus $(\mathrm{RA}=2.0)$, Red Sea eightline flasher Paracheilinus octotaenia ( $\mathrm{RA}=1.0)$, and Klunzinger's wrasse, Thalassoma rueppellii $(0.7 \%)$. The highest number of species $(S)$ per $500 \mathrm{~m}^{2}$ transect was found on reefs at the latitude $20^{\circ}$ in Saudi Arabia $(\mathrm{S}=21.8)$, and the lowest number of species was found at the latitude $15^{\circ}$ in Djibouti $(S=11.11)$. The highest mean abundance (8565.8) was found on reefs at latitude $20^{\circ}$ in Saudi Arabia and the lowest mean abundance (230) was found on reefs at latitude $22^{\circ}$, also in Saudi Arabia. Whereas, the highest Shannon-Wiener Diversity Index was found in reefs at the latitude $22^{\circ}\left(\mathrm{H}^{`}=2.4\right)$ and the lowest was found in reefs at the latitude $20^{\circ}\left(\mathrm{H}^{`}=0.6\right)$. This study revealed marked differences in the structure of ornamental fish assemblages with latitudinal distribution. The data support the presence of two major biogeographic groups of fishes in the Red Sea and Gulf of Aden: the southern Red Sea and Gulf of Aden group and the group in the northern and central Red Sea. Strong correlations were found between live coral cover and the number of fish species, abundance and Shannon-Wiener Diversity indices, and the strength of these correlations varied among the reefs. A conclusion was done that environmental differences among the reefs and the habitats investigated were important components of abundance variations and species diversity of ornamental fish along latitudinal gradients in the Red Sea and the Gulf of Aden.
\end{abstract}

Copyright M.A. Khalaf, M.Abdallah. This is an open access article distributed under the terms of the Creative Commons Attribution International License (CC BY 4.0), which permits unrestricted use, distribution, and reproduction in any medium, provided the original author and source are credited. 


\section{Keywords}

Fish community structure, coral reef fishes, Aquarium fishes, Biogeographical affinities, Red Sea and Gulf of Aden

\section{Introduction}

Coral reefs are valuable and important ecosystems. They are among the most productive and diverse of all-natural ecosystems, and they are often called «the tropical rain forests of the sea» (Bourilere and Harmelin 1989). Coral reefs have many functions, amongst which is the provision of a variety of habitats for a wealth of organisms. Fishes are a dominant group of coral reef fauna, in terms of both their biomass and diversity. They are the most visible and important mobile component in the coral reefs (Letourneur et al. 1999). Reef ecosystems provide fishes with shelter, feeding, spawning and nursery grounds. Pollution, destructive fishing, over-fishing, coral bleaching, tourism development and other stresses and activities threaten these valuable ecosystems.

While the Red Sea fish fauna is taxonomically quite well known (Randall 1992, Goren and Dor 1994, Khalaf 2004) compared with other parts of the tropical IndoPacific Ocean, the community structure of shore fishes has been less well investigated (Khalaf and Kochzius 2002). Despite a long tradition of taxonomical work (e.g. Forsskal 1775, Klunzinger 1884), few studies have been published on the general community structure of the Red Sea shore fishes (Bouchon-Navaro 1980, Ben-Tuvia et al. 1983, Rilov and Benayahu 2000, Khalaf and Kochzius 2002, Alwany and Stachowitsch 2007) and these studies cover a small range of spatial distribution. Most species of near-shore fishes in the Red Sea associate with coral reefs, although some occur in sea grasses, sandy areas, and other near-shore habitats (UNEP 1997). The present study was carried out through the Sustainable Use and Management of Living Marine Resources component of the Strategic Action Programme for the Red Sea and Gulf of Aden (SAP) executed by The Regional Organization for the Conservation of the Environment of the Red Sea and Gulf of Aden (PERSGA) between 1999 and 2003. The study was conducted at coral reef sites to assemble comparative regional data on the distribution of fifty ornamental fish species at latitudinal $\left(11-29^{\circ} \mathrm{N}\right)$ spatial scales. The main objectives of the study were to assess the community structure, and biogeographic affinities of Red Sea coral reef fishes that are collected for the aquarium trade.

\section{Material and methods}

\section{Study area}

The study was conducted at coral reef sites at latitudes between $11-29^{\circ} \mathrm{N}$ along the coasts of Jordan, Egypt, Saudi Arabia, Yemen in the Red Sea and just outside the Red Sea in the Gulf of Aden, for Djibouti (Fig. 1). 


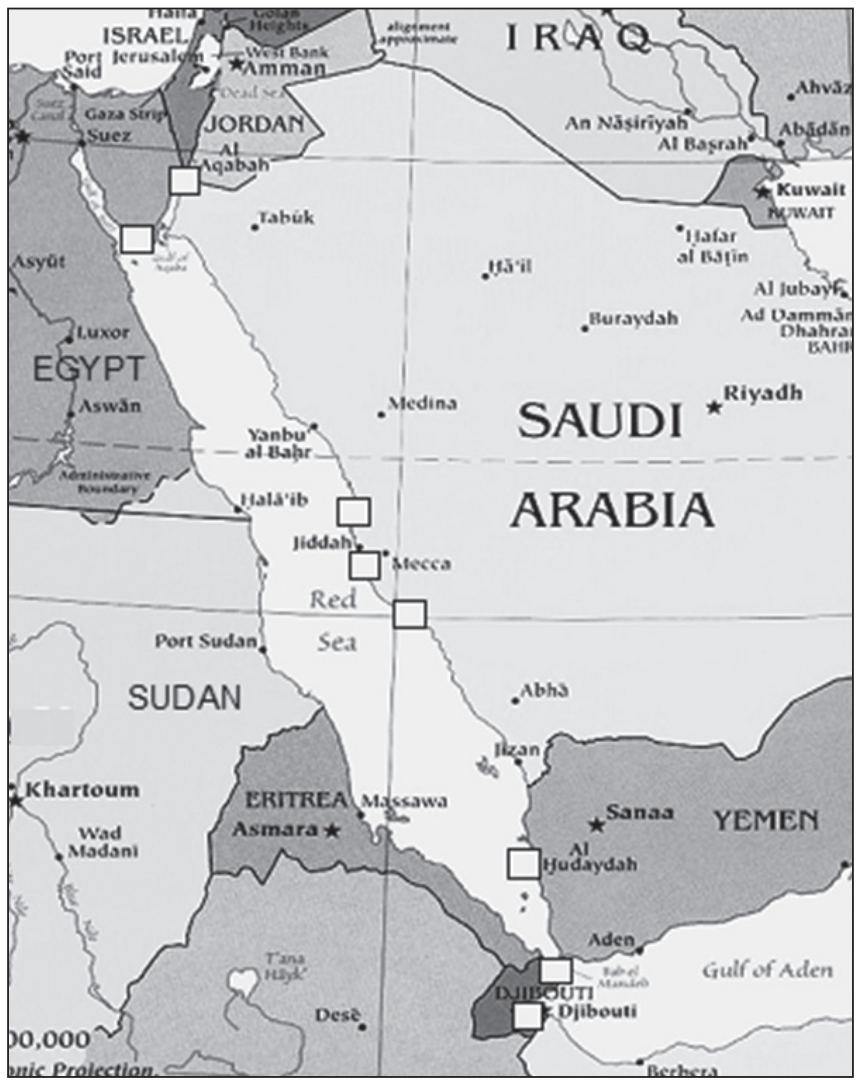

Figure I. Map of the Red Sea and Gulf of Aden. Squares indicate the coral reef sites examined in the present study.

\section{Visual census}

We selected 50 ornamental reef fish species that occur in shallow water habitats on coral reefs only. Based on the information collected from fishermen and Government authorities in member countries of (PERSGA), most of the sites and depths in Egypt, Saudi Arabia and Yemen were selected in sites used by collectors of the ornamental fishes. Whereas, the sites in Jordan and Djibouti were collection of ornamental fishes did not take place was carried out in coral reef sites. The abundance of each species was surveyed along the coasts of Jordan, Egypt, Saudi Arabia, Yemen and Djibouti using a visual census technique by SCUBA divers, as described in English et al. (1994). The visual census technique is a widely used method for ecological studies of fishes on coral reefs. However, differences in skill levels and techniques of observers can be a source of imprecision and/or bias (Thompson and Mapstone 1997). Therefore, only underwater fish counting performed by the first author was used to avoid this type of bias in the present study. A total of 118 transects, each $100 \mathrm{~m}$ length $\times 5 \mathrm{~m}$ width $\left(500 \mathrm{~m}^{2}\right)$ were performed at 29 sites (3-6 transects per site except at Ras Mohamed two transects instead of three at $2-4 \mathrm{~m}$ depth were surveyed due to the strong 


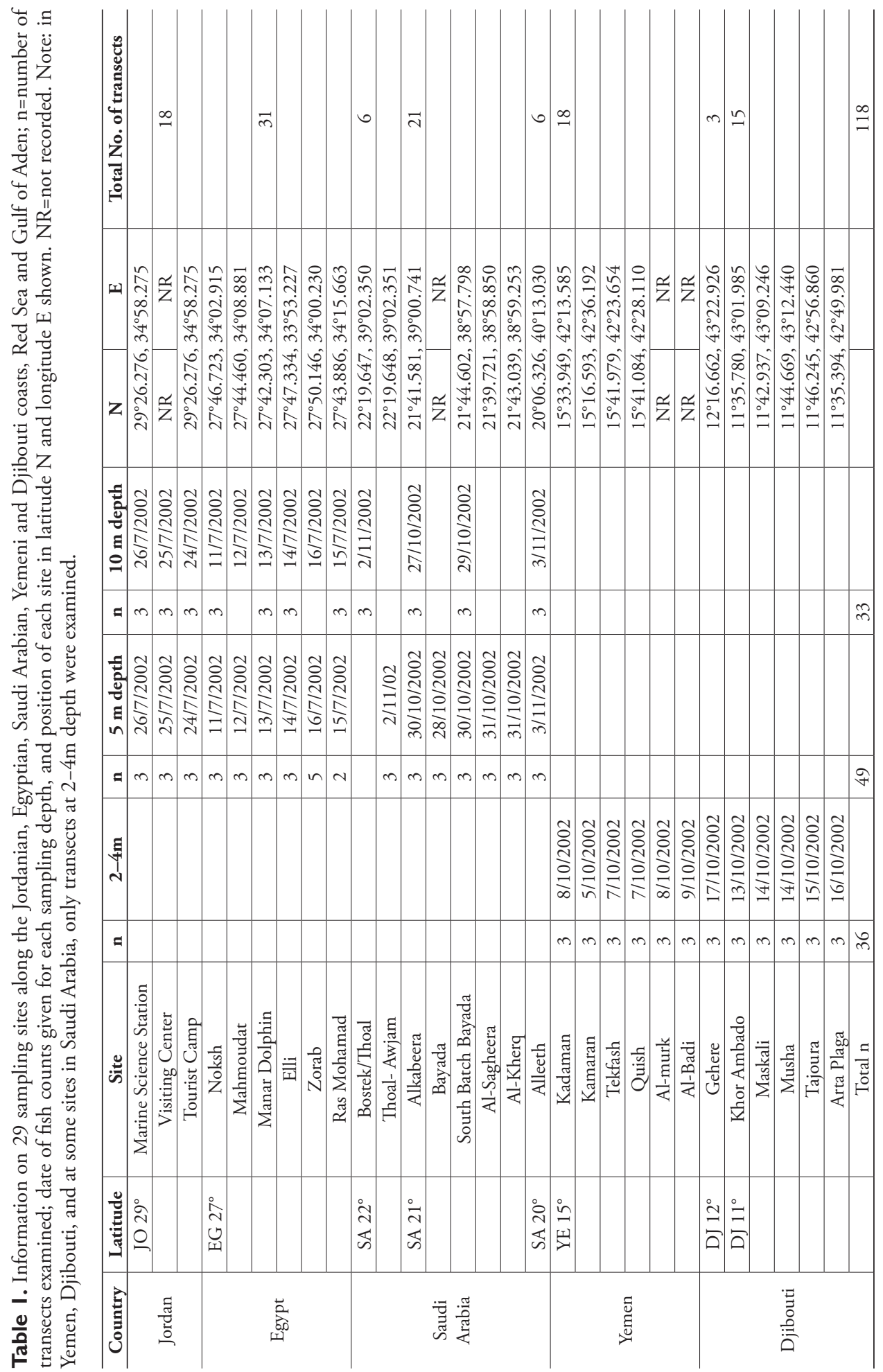


water currents occurred during the period of study, Table 1). At each site, a visual census was conducted along three transects, in most cases on the shallow reef slope (4-5 m) and also three transects on the deep reef slope $(8-10 \mathrm{~m})$. Divers then swam along the transects and recorded individuals of the 50 selected fish species within $2.5 \mathrm{~m}$ either side, and $3 \mathrm{~m}$ above the transect line for a duration of 25-30 minutes. Fish identification in the field was checked using published guides (Myers 1991, Randall 1992, Smith and Heemstra 1986, Khalaf and Disi 1997). The common name of fishes indicated in this study were after Froese and Pauly 2000 (FishBase 2013). All latitude numbers are for north latitudes.

Surveys of the benthic habitat were carried out by assistants from Saudi Arabia and Yemen. The line-point intercept method was used with the tape stretched taut 200 points recorded per $100-\mathrm{m}$ transect. From this point-intercept data, the percentage cover was calculated of live hard coral, live soft coral, dead coral, coral rock, sand, rubble, macro algae, algal turf, sponge, and others as described by Edwards (2002).

\section{Statistical analysis}

Abundance of fishes was described by relative abundance (RA) and frequency of appearance (FA) following Khalaf et al. (2006). RA was calculated as: (pooled average abundance of species $\underline{i}$ at each depth and site / pooled average abundance of all species at each depth and site) $\times 100$. FA was determined as: (number of transects in which species $i$ was present / total number of transects) X 100. Species richness (number of species), and Shannon-Weiner species diversity were calculated using PRIMER-E (Polymouth Marine Laboratory, UK, 2000). Multivariate analysis of the data such as cluster analysis was performed using the same software. Analysis of a linear regression test used to examine the relationship between hard coral (HC) and soft coral (SC) vs. species richness $(\mathrm{S})$, fish abundance $(\mathrm{N})$, Shannon-Weiner Diversity Index $\left(\mathrm{H}^{\prime}\right)$ as described by Sokal and Rohlf (1981) and implemented using STAT VEIW computer software.

\section{Results}

\section{Benthic habitat}

Fig. 2 shows the percentage cover of substrate types for various latitudes along the Red Sea and Gulf of Aden.

\section{Jordan}

Latitude $29^{\circ}$

Along the Jordanian Gulf of Aqaba coast, the highest hard live coral cover was $47 \%$, occurring at the Visitor Center at $10 \mathrm{~m}$ depth. The average live hard coral cover across all sites in Jordan was $27 \%$. The highest soft coral cover was at the Visitor Center at $5 \mathrm{~m}$ depth, and the average among all Jordanian sites was $6 \%$. 


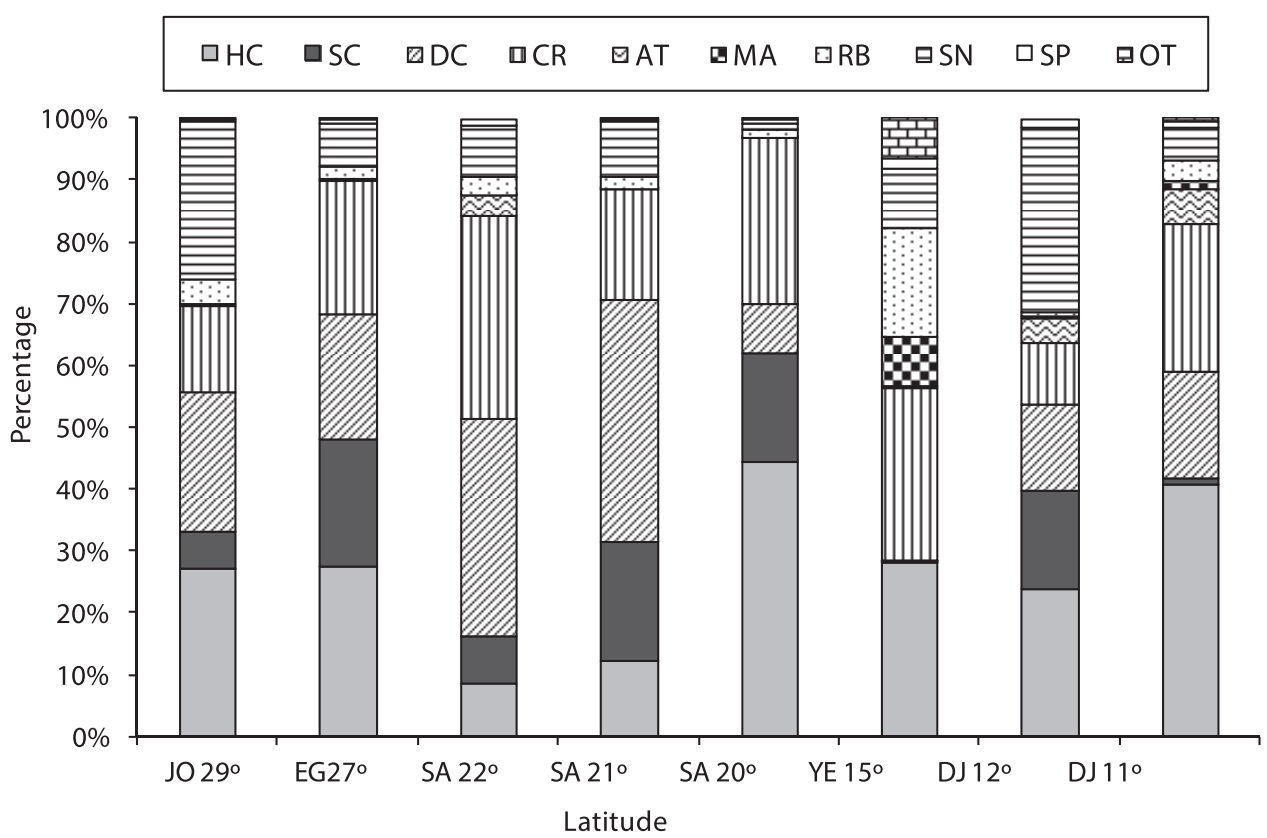

Figure 2. Percent cover (\%) for substrate types at all latitudes [(JO=Jordan, EG=Egypt, SA= Saudi Arabia, YE=Yemen, $\mathrm{DJ}=\mathrm{D}$ jibouti), where $(\mathrm{HC}=\mathrm{Hard}$ coral, $\mathrm{SC}=$ Soft coral, $\mathrm{DC}=$ Dead coral, $\mathrm{CR}=\mathrm{Coral}$ rock, $\mathrm{AT}=$ Algal turf, $\mathrm{MA}=$ Macroalgae, $\mathrm{RB}=$ Rubble, $\mathrm{SN}=$ Sand, $\mathrm{SP}=$ Sponge, $\mathrm{OT}=$ Others)].

\section{Egypt}

\section{Latitude $27^{\circ}$}

Along the Egyptian coast, the highest hard coral cover was $41.2 \%$, found at both Noksh (5 $\mathrm{m}$ depth) and at Mahmoudat (5 $\mathrm{m}$ depth). The average of hard coral cover at all Egyptian sites was 27.6\%. The highest soft coral cover was 47.8\% at Fanar Dolphin and Ras Mohammed respectively, both at $10 \mathrm{~m}$ depth. The average soft coral cover at all sites in Egypt was 20.6\%.

\section{Saudi Arabia}

Latitude $22^{\circ}$

At latitude $22^{\circ}$, the highest hard coral cover was $14 \%$, occurring at Thowal-Awjam at $4 \mathrm{~m}$ depth. The average hard live coral at all sites at this latitude was $8.8 \%$. The highest soft coral cover was $5.5 \%$ in Thoal-Bostek, at $10 \mathrm{~m}$ deep, and the average soft coral cover at all sites at this latitude was 7.7\%.

\section{Latitude $21^{\circ}$}

The highest hard live coral cover was $35.5 \%$ at Bayada, in the deep transect. The average hard live coral cover at all sites was $12.4 \%$. The highest soft coral cover was $81.5 \%$ at Alkabeera at $4 \mathrm{~m}$ deep, and the average soft coral cover at all sites was $19.2 \%$. 


\section{Latitude $20^{\circ}$}

The highest hard coral cover was $52.5 \%$ at Alleeth in shallow transects. The average hard live hard coral in all transects was $44.4 \%$. The highest soft coral cover was $32.0 \%$, and the average of all transects was $17.5 \%$.

\section{Yemen}

Latitude $15^{\circ}$

The highest hard coral cover along the Yemeni Red Sea Coast was $40.5 \%$ at Tekfash. The average live hard coral cover at all sites was $26.2 \%$. The highest soft coral was $0.3 \%$ at Tekfash. The average soft coral cover at all sites was $0.1 \%$.

\section{Djibouti}

The below sites were in the Gulf of Aden.

\section{Latitude $12^{\circ}$}

The highest hard coral cover was 32.5\% recorded at Gehere in shallow transects. The average hard live coral cover at all sites was $23.8 \%$. The highest soft coral cover was $17.5 \%$ recorded at Gehere in shallow transects. The average of soft coral cover at all sites was $15.8 \%$.

\section{Latitude $11^{\circ}$}

The highest live hard coral cover was $71.0 \%$ at Tadjoura in shallow transects. The lowest hard live coral cover was $14.0 \%$ at Maskali in shallow transects. The highest soft coral cover was $2.5 \%$ at Musha. The average soft coral cover at all transects was 3.4\%.

The overall mean percentage cover for both hard and soft coral (HC and SC combined) from highest to lowest was as follows: The highest was $61.9 \%$ total coral cover at latitude $20^{\circ}$ along the Saudi Arabia coast, then $48.2 \%$ at latitude $27^{\circ}$ along the Egyptian coast, 44.1 and 39.7 at latitude 11 and $12^{\circ}$ respectively, 33.3\% at latitude $29^{\circ}$ along the Jordanian coast, 31.6 at Latitude 21 at Saudi Arabia coast, $26.3 \%$ at latitude $15^{\circ}$ at the Yemeni coast, and the lowest combined total coral cover was $16.4 \%$ at latitude $22^{\circ}$ along the Saudi Arabia coast.

\section{Fish assemblages and community indices Dominant taxa and fish community structure}

\section{Jordan}

Latitude $29^{\circ}$

A total of 29,485 fishes were counted along the 18 transects examined at latitude $29^{\circ}$. The mean fish abundance ranged from 475 individuals per transect on the Tourist Camp reef at $5 \mathrm{~m}$ depth, to 3,117 individuals per transect on the Visitor Center reef at $5 \mathrm{~m}$ depth. The mean fish abundance across all transects was 1,638 individuals per transect. Of the 50 fish species considered, only 35 were observed at Jordanian 
sites. The number of species observed ranged from 23 at $10 \mathrm{~m}$ depth at the Tourist Camp, to 30 at $5 \mathrm{~m}$ depth at the Marine Science Station, with an average of 19.6 species per transect (Fig. 3). In terms of relative abundance (RA) on Jordanian reefs, the 5 most abundant fish species examined was the Sea goldie, Pseudanthias squamipinnis (Peters, 1855) $(\mathrm{RA}=40.7 \%)$, followed by Blue green damselfish, Chromis viridis (Cuvier, 1830) (RA=27.5\%), Whitetail dascyllus, Dascyllus aruanus (Linnaeus, 1758) $(\mathrm{RA}=7.7 \%)$, Red Sea eightline flasher, Paracheilinus octotaenia Fourmanoir, 1955 in Roux-Estève and Fourmanoir 1955 (RA=7.3\%), and Marginate dascyllus, Dascyllus marginatus (Rüppell, 1829) (RA=6.8\%). Together, these five species made up $90 \%$ of the abundance of the 50 fish species examined (Table 2).

In terms of frequency of appearance, the most common species were P. squamipinnis, D. aruanus, D. marginatus, Twoband anemonefish, Amphiprion bicinctus Rüppell, 1830, Eritrean butterflyfish Chaetodon paucifasciatus Ahl, 1923 (100\% each), C. viridis, Fourline wrasse, Larabicus quadrilineatus (Rüppell, 1835), Green birdmouth wrasse, Gomphosus caeruleus Lacepède, 1801, and Yellowbreasted wrasse, Anampses twistii Bleeker, 1856 (94.4\% each) (Table 3).

\section{Egypt}

Latitude $27^{\circ}$

A total of 196,379 fish individuals were counted along 32 transects which were examined at the latitude $27^{\circ}$. The mean abundance ranged from 310 individuals at Mahmoudat at $10 \mathrm{~m}$ depth, to 13,358 individuals per transect at Fanar Al-Dolphin at $5 \mathrm{~m}$ depth. The mean fish abundance of all transects was 6,334 individuals per transect. Of the 50 fish species considered, only 43 were reported from Egyptian sites. The number of species observed ranged from 26 at Mahmoudat (10 m depth) to 34 at $\mathrm{Al}$ Noksh (9 m depth), with a mean of 20.6 species per transect (Fig. 3).

In terms of relative abundance (RA) on Egyptian reefs, the most abundant species was $P$. squamipinnis $(\mathrm{RA}=84.6 \%)$, followed by $C$. viridis $(\mathrm{RA}=10.4 \%)$; these two species made up $95 \%$ of all the fishes recorded in Egypt (Table 2).

In terms of frequency of appearance (FA), the most common species was, Bluestreak cleaner wrasse Labroides dimidiatus (Valenciennes, 1839 in Cuvier and Valenciennes 1839) at $94 . \%$, followed by Blacktail butterflyfish, Chaetodon austriacus Rüppell, 1836 and Klunzinger's wrasse, Thalassoma rueppellii (Klunzinger, 1871) (90\%, each); other common species were G. caeruleus, Threadfin butterflyfish, Chaetodon auriga Forsskål, 1775 (87\%, each), Blackside hawkfish, Paracirrhites forsteri (Schneider, 1801 in Bloch and Schneider 1801) (84\%), and C. paucifasciatus (81\%) (Table 3).

\section{Saudi Arabia}

Latitude $22^{\circ}$

A total of 1,380 fishes were counted along the 6 transects performed in Saudi Arabia at latitude $22^{\circ} \mathrm{N}$. Fish abundance ranged from 145 individuals per transect in Bostek/Thoal at $10 \mathrm{~m}$ deep, to 297 individuals per transect in Bostek/Thoal at $10 \mathrm{~m}$ deep. The mean fish abundance in all transects was 230 fish per transect. Of the 50 


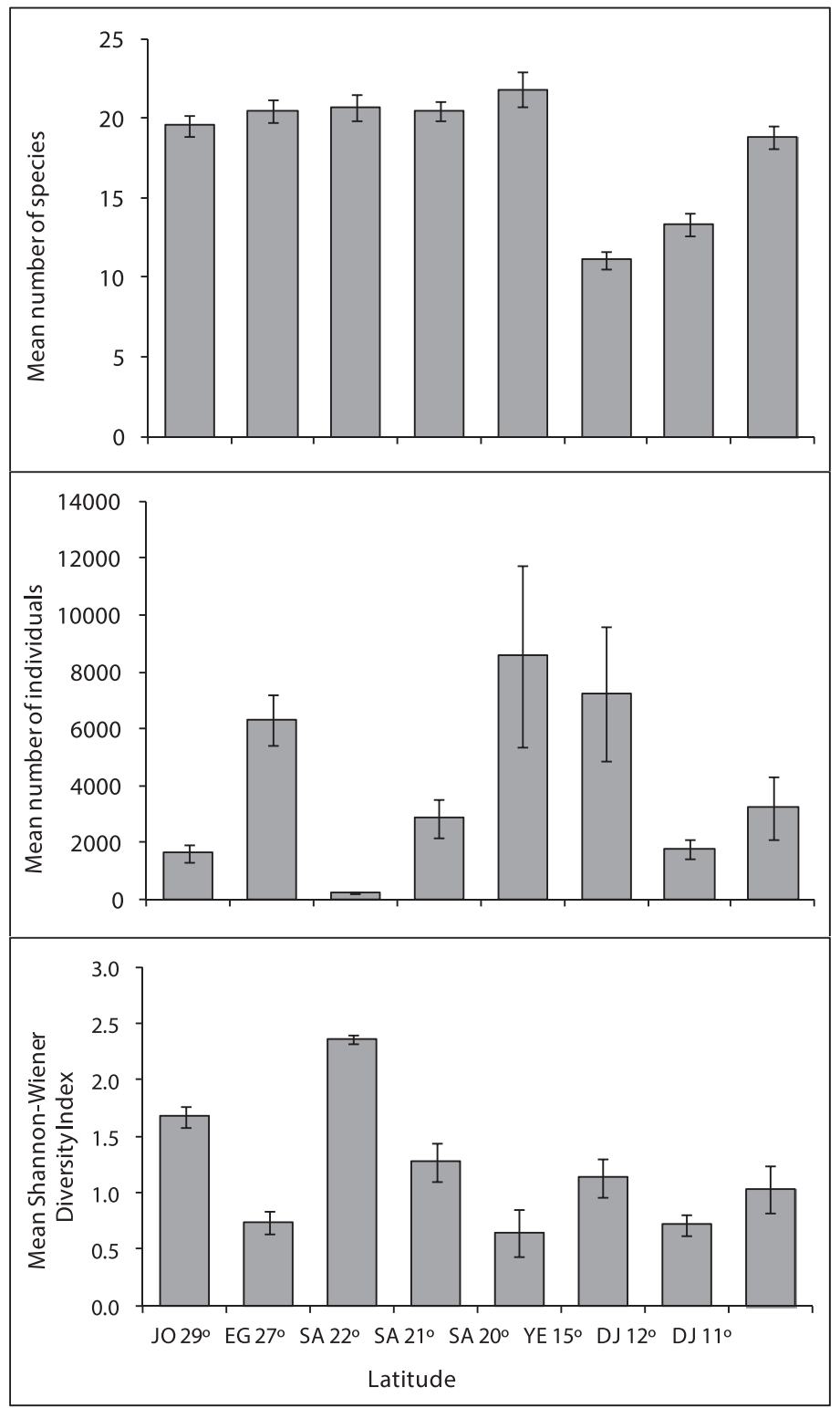

Figure 3. Mean number of fish species, mean number of individuals, and mean Shannon-Wiener Diversity Index in coral reef along the Jordan latitude 29 $9^{\circ}$; Egypt latitude $27^{\circ}$; Saudi Arabia latitude 22, 21, $20^{\circ}$; Yemen $15^{\circ}$ and Djibouti latitude $12,11^{\circ}$.

species considered, only 35 were reported from this latitude, with a mean of 20.7 species per transect (Fig. 3).

In terms of relative abundance (RA), the most abundant fish species was $P$. sqamipinnis $(\mathrm{RA}=16.7 \%)$, followed by Sohal surgeonfish Acanthurus sohal (Forsskål, 1775) $(\mathrm{RA}=12.4 \%)$, L. quadrilineatus $(\mathrm{RA}=12.3)$, G. caeruleus $(\mathrm{RA}=6.9)$, and Sunrise dot- 
Table 2. Relative abundance in $\%$ of fish individuals per $500 \mathrm{~m}^{2}$ transect along reefs at JO= Jordan latitude $29^{\circ}$; EG=Egypt latitude $27^{\circ}$; SA=Saudi Arabia latitude 22, 21, 20 ; YE=Yemen $15^{\circ}$ and DJ=Djibouti latitude $12,11^{\circ}$. (TRA indicates total relative abundance per family).

\begin{tabular}{|c|c|c|c|c|c|c|c|c|c|c|}
\hline Fish scientific name & Fish common name & \begin{tabular}{|l|} 
JO \\
$29^{\circ}$ \\
\end{tabular} & \begin{tabular}{|l|} 
EG \\
$27^{\circ}$ \\
\end{tabular} & \begin{tabular}{|l|} 
SA \\
$22^{\circ}$ \\
\end{tabular} & \begin{tabular}{|c|} 
SA \\
$21^{\circ}$ \\
\end{tabular} & \begin{tabular}{|c|} 
SA \\
$20^{\circ}$ \\
\end{tabular} & \begin{tabular}{|c|}
$\mathrm{YE}$ \\
$15^{\circ}$ \\
\end{tabular} & $\begin{array}{l}\text { DJ } \\
12^{\circ} \\
\end{array}$ & $\begin{array}{l}\text { DJ } \\
11^{\circ} \\
\end{array}$ & $\begin{array}{c}\text { Total } \\
\text { RA } \\
\end{array}$ \\
\hline Scorpaenidae & & & & & & & & & & 0,01 \\
\hline Pterois miles & Devil firefish & 0,0 & 0,0 & 0,0 & 0,0 & 0,0 & 0,0 & 0,0 & 0,0 & 0,00 \\
\hline Pterois radiata & Radial firefish & 0,0 & 0,0 & 0,0 & 0,0 & 0,0 & 0,0 & 0,0 & 0,0 & 0,01 \\
\hline Serranidae & & & & & & & & & & 34,71 \\
\hline Pseudanthias squamip & & 40,7 & 84,6 & 16,7 & 3,9 & 1,5 & 0,0 & 0,0 & 0,0 & 34,71 \\
\hline Pseudochromidae & & & & & & & & & & 0,28 \\
\hline Pseudochromis flavivertex & Sunrise d & 0,0 & 0,0 & 6,7 & 0,0 & 0,0 & 0,0 & 0,0 & 0,0 & 0,03 \\
\hline Pseudochromis fridmani & Orchid d & 0,8 & 0,4 & 0,9 & 0,2 & 0,1 & 0,0 & 0,0 & 0,0 & 0,23 \\
\hline Pseudochromis springeri & yback & 0,1 & 0,0 & 0,0 & 0,0 & 0,0 & 0,0 & 0,0 & 0,0 & 0,02 \\
\hline Chaetodontidae & & & & & & & & & & 0,96 \\
\hline Chaetodon auriga & & 0,0 & 0,2 & 1,2 & 0,1 & 0,0 & 0,0 & 0,0 & 0,0 & 0,10 \\
\hline & & 0,5 & 0,2 & 2,3 & 0,2 & 0,0 & 0,0 & 0,0 & 0,0 & 0,13 \\
\hline Chaetodon fasciatus & iago & 0,1 & 0,1 & 1,3 & 0,1 & 0,0 & 0,0 & 0,0 & 0,1 & 0,06 \\
\hline Chaetodon larvatus & $\mathrm{H}$ & 0,0 & 0,0 & 1,2 & 0,1 & 0,2 & 0,8 & 0,2 & 0,4 & 0,27 \\
\hline & & 0,0 & 0,0 & 0,1 & 0,0 & 0,0 & 0,0 & 0,0 & 0,0 & 0,00 \\
\hline Chaetodon melannotus & f & 0,0 & 0,0 & 0,0 & 0,1 & 0,0 & 0,0 & 0,0 & 0,0 & 0,03 \\
\hline Chaetodon melapterus & $A$ & 0,0 & 0,0 & 0,0 & 0,0 & 0,0 & 0,0 & 0,4 & 0,2 & 0,02 \\
\hline & & 0,0 & 0,0 & 0,0 & 0,0 & 0,0 & 0,0 & 0,0 & 0,1 & 0,01 \\
\hline Chaetodon paucifasc & Eritr & 1,5 & 0,1 & 0,0 & 0,1 & 0,0 & 0,0 & 0,0 & 0,0 & 0,14 \\
\hline Chaetodon semilarvatus & 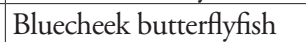 & 0,0 & 0,0 & 0,1 & 0,0 & 0,0 & 0,0 & 0,1 & 0,1 & 0,03 \\
\hline & & 0,0 & 0,1 & 0,0 & 0,0 & 0,0 & 0,0 & 0,1 & 0,1 & 0,07 \\
\hline Chaetodon vagabundus & & 0,0 & 0,0 & 0,0 & 0,0 & 0,0 & 0,0 & 0,3 & 0,1 & 0,01 \\
\hline Heniochus acuminatus & $\mathrm{P}$ & 0,0 & 0,0 & 0,0 & 0,0 & 0,0 & 0,0 & 0,0 & 0,0 & 0,00 \\
\hline Heniochus intermedius & & 0,1 & 0,0 & 3,4 & 0,1 & 0,0 & 0,1 & 0,1 & 0,3 & 0,10 \\
\hline Pomacanthidae & & & & & & & & & & 0,18 \\
\hline Pomacanthus asfur & 1 & 0,0 & 0,0 & 1,7 & 0,0 & 0,0 & 0,1 & 0,1 & 0,1 & 0,06 \\
\hline Pomacanthus impera & & & 0,0 & 0,0 & 0,0 & 0,0 & 0,0 & 0,0 & 0,0 & 0,00 \\
\hline Pomacanthus maculosus & $\mathrm{Y}$ & 0,0 & 0,0 & 0,5 & 0,0 & 0,0 & 0,3 & 0,1 & 0,1 & 0,08 \\
\hline Pygoplites diacanthus & & 0,0 & 0,0 & 0,7 & 0,1 & 0,0 & 0,0 & 0,0 & 0,1 & 0,04 \\
\hline & & & & & & & & & & 59,39 \\
\hline Amphiprion bicinctus & & 1,5 & 0,0 & 0,4 & 0,0 & 0,0 & 0,0 & 0,0 & 0,0 & 0,12 \\
\hline Chromis viridis & & 27,5 & 10,4 & 0,0 & 73,9 & 92,3 & 88,8 & 83,8 & 90,8 & 54,40 \\
\hline Dascyllus aruanus & & 7,7 & 0,2 & 0,6 & 17,3 & 0,1 & 0,3 & 0,0 & 0,4 & 2,61 \\
\hline Dascyllus marginatus & Marginate dascyllus & 6,8 & 0,3 & 0,0 & 0,0 & 0,1 & 5,8 & 0,0 & 0,1 & 1,95 \\
\hline Dascyllus trimaculatus & & & 0,0 & 0,0 & 0,1 & & 1,0 & 0,0 & 0,0 & \\
\hline \multicolumn{11}{|l|}{ Cirrhitidae } \\
\hline Paracirrhites forsteri & 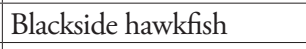 & 0,0 & 0,1 & 0,3 & 0,3 & 0,0 & 0,0 & 0,0 & 0,0 & 0,08 \\
\hline & & & & & & & & & & 3,45 \\
\hline Anampses twistii & & 0,6 & 0,1 & 0,5 & 0,1 & 0,0 & 0,0 & 0,0 & 0,0 & 0,09 \\
\hline Bodianus anthioides & Lyretail hogfish & 0,1 & 0,0 & 0,4 & 0,0 & 0,0 & 0,0 & 0,0 & 0,0 & 0,02 \\
\hline Cheilinus lunulatus & roomtail wrasse & 0,0 & 0,0 & 1,3 & 0,0 & 0,0 & 0,0 & 0,0 & 0,0 & 0,04 \\
\hline Coris aygula & & 0,0 & 0,1 & 0,1 & 0,0 & 0,0 & 0,0 & 0,0 & 0,0 & 0,03 \\
\hline Gomphosus caeruleus & reen birdmouth wrasse & 0,5 & 0,2 & 6,9 & 0,6 & 0,2 & 0,0 & 1,2 & 0,5 & 0,26 \\
\hline Labroides dimidiatus & Bluestreak cleaner wrasse & 0,1 & 0,2 & 3,6 & 0,2 & 0,0 & 0,0 & 0,2 & 0,1 & 0,12 \\
\hline
\end{tabular}




\begin{tabular}{l|l|c|c|c|c|c|c|c|c|c}
\hline Fish scientific name & Fish common name & $\begin{array}{c}\text { JO } \\
\mathbf{2 9}^{\circ}\end{array}$ & $\begin{array}{c}\text { EG } \\
\mathbf{2 7}^{\circ}\end{array}$ & $\begin{array}{c}\text { SA } \\
\mathbf{2 2}^{\circ}\end{array}$ & $\begin{array}{c}\mathbf{S A} \\
\mathbf{2} \mathbf{1}^{\circ}\end{array}$ & $\begin{array}{c}\mathbf{S A} \\
\mathbf{2 0}^{\circ}\end{array}$ & $\begin{array}{c}\mathbf{Y E} \\
\mathbf{1 5}\end{array}$ & $\begin{array}{c}\mathbf{D J} \\
\mathbf{1 2}^{\circ}\end{array}$ & $\begin{array}{c}\mathbf{D J} \\
\mathbf{1 1}\end{array}$ & $\begin{array}{c}\text { Total } \\
\mathbf{R A}\end{array}$ \\
\hline Larabicus quadrilineatus & Fourline wrasse & 0,4 & 0,1 & 12,3 & 0,2 & 0,4 & 1,6 & 4,1 & 1,7 & 0,74 \\
\hline Novaculichthys taeniourus & Rockmover wrasse & 0,0 & 0,0 & 0,0 & 0,0 & 0,0 & 0,0 & 0,0 & 0,0 & 0,00 \\
\hline Paracheilinus octotaenia & Red Sea eightline flasher & 7,3 & 0,3 & 1,1 & 0,0 & 3,9 & 0,1 & 0,0 & 0,7 & 0,98 \\
\hline Thalassoma rueppellii & Klunzinger's wrasse & 2,6 & 1,2 & 6,1 & 0,7 & 0,2 & 0,0 & 0,0 & 0,0 & 0,72 \\
\hline Thalassoma lunare & Moon wrasse & 0,0 & 0,0 & 5,6 & 0,2 & 0,2 & 0,6 & 7,6 & 1,5 & 0,45 \\
\hline Acanthuridae & & & & & & & & & & 0,88 \\
\hline Acanthurus sohal & Sohal surgeonfish & 0,0 & 0,7 & 12,4 & 0,3 & 0,3 & 0,2 & 0,4 & 0,5 & 0,43 \\
\hline Naso lituratus & Orangespine unicornfish & 0,0 & 0,1 & 2,9 & 0,1 & 0,1 & 0,0 & 0,0 & 0,8 & 0,14 \\
\hline Zebrasoma veliferum & Sailfin tang & 0,1 & 0,1 & 6,4 & 0,5 & 0,0 & 0,0 & 0,0 & 0,2 & 0,14 \\
\hline Zebrasoma xanthurum & Yellowtail tang & 0,3 & 0,1 & 0,9 & 0,2 & 0,0 & 0,0 & 1,2 & 1,0 & 0,17 \\
\hline Balistidae & & & & & & & & & & 0,04 \\
\hline Balistapus undulatus & Orange-lined triggerfish & 0,0 & 0,0 & 0,8 & 0,1 & 0,0 & 0,0 & 0,0 & 0,0 & 0,03 \\
\hline Balistoides viridescens & Titan triggerfish & 0,0 & 0,0 & 0,1 & 0,0 & 0,0 & 0,0 & 0,0 & 0,0 & 0,00 \\
\hline Rhinecanthus assasi & Picasso triggerfish & 0,0 & 0,0 & 0,0 & 0,0 & 0,0 & 0,0 & 0,0 & 0,0 & 0,01 \\
\hline Ostraciidae & & & & & & & & & & 0,00 \\
\hline Ostracion cubicus & Yellow boxfish & 0,0 & 0,0 & 0,2 & 0,0 & 0,0 & 0,0 & 0,0 & 0,0 & 0,00 \\
\hline Tetraodontidae & & & & & & & & & & 0,01 \\
\hline Arothron diadematus & Masked puffer & 0,0 & 0,0 & 0,4 & 0,0 & 0,0 & 0,0 & 0,0 & 0,0 & 0,01 \\
\hline
\end{tabular}

tyback Pseudochromis flavivertex Rüppell, 1835 (RA=6.7), these five species accounted for $54.93 \%$ of all fish species recorded from this latitude (Table 2).

In terms of frequency of appearance (FA), the most common species were Sailfin tang Zebrasoma veliferum (Bloch, 1795), Hooded butterflyfish Chaetodon larvatus $\mathrm{Cu}-$ vier, 1831, Heniochus intermedius Steindachner, 1893, L. dimidiatus, L. quadrilineatus and $G$. caeruleus $(\mathrm{FA}=100 \%$, each) (Table 3$)$.

Latitude $21^{\circ}$

A total of 60,096 fishes were counted along the 21 transects performed in Saudi Arabia at latitude $21^{\circ}$. Fish abundance ranged from 116 individuals per transect in Alkabeera site at $4 \mathrm{~m}$ deep to 9,480 individuals per transect in South Batch Bayada at $10 \mathrm{~m}$ deep. The mean fish abundance in all transects was 2861.7 individuals per transect. Of the 50 species considered, only 40 were reported from this latitude, with a mean of 20.5 species per transect (Fig. 3).

In terms of relative abundance (RA), the most abundant fish species was $C$. viridis (RA $=73.9 \%)$, followed by $D$. aruanus $(\mathrm{RA}=17.3 \%)$, and P. sqamipinnis $(\mathrm{RA}=3.9 \%)$. These three species accounted $95.04 \%$ of all fish species recorded from this latitude (Table 2).

In terms of frequency of appearance (FA), the most common species were $G$. caeruleus and L. dimidiatus, $(\mathrm{FA}=100 \%$, each) followed by C. austriacus ( $\mathrm{FA}=95.5 \%)$, Diagonal butterflyfish Chaetodon fasciatus Forsskål, 1775 and $P$. forsteri (FA= 90.5\%, each) (Table 3).

Latitude $20^{\circ}$

A total of 51,395 fishes were counted along the 6 transects performed in Saudi Arabia at latitude $20^{\circ}$. Fish abundance ranged from 1278 individuals per transect in Alleeth at 
Table 3. Frequency of appearance in $\%$ of fish individuals per $500 \mathrm{~m}^{2}$ transect along reefs at JO= Jordan latitude $29^{\circ}$; EG=Egypt latitude $27^{\circ}$; SA=Saudi Arabia latitude 22, 21, 20 ; YE=Yemen $15^{\circ}$ and DJ=Djibouti latitude $12,11^{\circ}$.

\begin{tabular}{|c|c|c|c|c|c|c|c|c|}
\hline Fish species & JO 29 ${ }^{\circ}$ & EG $27^{\circ}$ & SA $22^{\circ}$ & SA $21^{\circ}$ & SA $20^{\circ}$ & YE $15^{\circ}$ & DJ $12^{\circ}$ & DJ $11^{\circ}$ \\
\hline \multicolumn{9}{|l|}{ Scorpaenidae } \\
\hline Pterois miles & 16,7 & 29,0 & 0,0 & 0,0 & 0,0 & 0,0 & 0,0 & 0,0 \\
\hline Pterois radiata & 22,2 & 29,0 & 0,0 & 0,0 & 16,7 & 0,0 & 0,0 & 20,0 \\
\hline \multicolumn{9}{|l|}{ Serranidae } \\
\hline Pseudanthias squamipinnis & 100,0 & 80,6 & 50,0 & 33,3 & 83,3 & 0,0 & 0,0 & 0,0 \\
\hline \multicolumn{9}{|l|}{ Pseudochromidae } \\
\hline Pseudochromis flavivertex & 0,0 & 0,0 & 50,0 & 19,0 & 0,0 & 22,2 & 0,0 & 0,0 \\
\hline Pseudochromis fridmani & 88,9 & 74,2 & 50,0 & 47,6 & 33,3 & 0,0 & 0,0 & 0,0 \\
\hline Pseudochromis springeri & 61,1 & 25,8 & 0,0 & 0,0 & 0,0 & 0,0 & 0,0 & 0,0 \\
\hline \multicolumn{9}{|l|}{ Chaetodontidae } \\
\hline Chaetodon auriga & 11,1 & 87,1 & 83,3 & 66,7 & 33,3 & 0,0 & 0,0 & 0,0 \\
\hline Chaetodon austriacus & 83,3 & 90,3 & 100,0 & 95,2 & 33,3 & 0,0 & 0,0 & 0,0 \\
\hline Chaetodon fasciatus & 72,2 & 74,2 & 66,7 & 90,5 & 50,0 & 16,7 & 33,3 & 66,7 \\
\hline Chaetodon larvatus & 0,0 & 3,2 & 100,0 & 76,2 & 100,0 & 100,0 & 100,0 & 100,0 \\
\hline Chaetodon lineolatus & 0,0 & 9,7 & 16,7 & 4,8 & 0,0 & 0,0 & 0,0 & 0,0 \\
\hline Chaetodon melannotus & 27,8 & 41,9 & 0,0 & 33,3 & 0,0 & 0,0 & 0,0 & 13,3 \\
\hline Chaetodon melapterus & 0,0 & 0,0 & 0,0 & 0,0 & 0,0 & 0,0 & 100,0 & 93,3 \\
\hline Chaetodon mesoleucos & 0,0 & 0,0 & 0,0 & 23,8 & 16,7 & 22,2 & 0,0 & 66,7 \\
\hline Chaetodon paucifasciatus & 100,0 & 80,6 & 0,0 & 57,1 & 16,7 & 0,0 & 0,0 & 0,0 \\
\hline Chaetodon semilarvatus & 0,0 & 45,2 & 16,7 & 33,3 & 50,0 & 50,0 & 33,3 & 73,3 \\
\hline Chaetodon trifascialis & 11,1 & 74,2 & 0,0 & 52,4 & 0,0 & 5,6 & 33,3 & 33,3 \\
\hline Chaetodon vagabundus & 0,0 & 0,0 & 0,0 & 0,0 & 0,0 & 0,0 & 100,0 & 73,3 \\
\hline Heniochus acuminatus & 0,0 & 0,0 & 0,0 & 0,0 & 0,0 & 0,0 & 0,0 & 6,7 \\
\hline Heniochus intermedius & 44,4 & 67,7 & 100,0 & 14,3 & 100,0 & 83,3 & 100,0 & 93,3 \\
\hline \multicolumn{9}{|l|}{ Pomacanthidae } \\
\hline Pomacanthus asfur & 0,0 & 0,0 & 66,7 & 0,0 & 83,3 & 94,4 & 33,3 & 86,7 \\
\hline Pomacanthus imperator & 5,6 & 19,4 & 0,0 & 0,0 & 16,7 & 5,6 & 33,3 & 0,0 \\
\hline Pomacanthus maculosus & 0,0 & 22,6 & 66,7 & 0,0 & 83,3 & 100,0 & 100,0 & 80,0 \\
\hline Pygoplites diacanthus & 5,6 & 54,8 & 66,7 & 14,3 & 100,0 & 0,0 & 0,0 & 80,0 \\
\hline \multicolumn{9}{|l|}{ Pomacentridae } \\
\hline Amphiprion bicinctus & 100,0 & 45,2 & 33,3 & 47,6 & 83,3 & 11,1 & 0,0 & 26,7 \\
\hline Chromis viridis & 94,4 & 54,8 & 0,0 & 71,4 & 100,0 & 55,6 & 100,0 & 93,3 \\
\hline Dascyllus aruanus & 100,0 & 22,6 & 33,3 & 61,9 & 66,7 & 16,7 & 0,0 & 46,7 \\
\hline Dascyllus marginatus & 100,0 & 19,4 & 0,0 & 0,0 & 33,3 & 50,0 & 0,0 & 20,0 \\
\hline Dascyllus trimaculatus & 44,4 & 16,1 & 0,0 & 4,8 & 33,3 & 11,1 & 0,0 & 13,3 \\
\hline \multicolumn{9}{|l|}{ Cirrhitidae } \\
\hline Paracirrhites forsteri & 0,0 & 83,9 & 33,3 & 90,5 & 16,7 & 0,0 & 0,0 & 0,0 \\
\hline \multicolumn{9}{|l|}{ Labridae } \\
\hline Anampses twistii & 94,4 & 77,4 & 33,3 & 66,7 & 50,0 & 0,0 & 0,0 & 53,3 \\
\hline Bodianus anthioides & 61,1 & 29,0 & 50,0 & 14,3 & 16,7 & 0,0 & 0,0 & 0,0 \\
\hline Cheilinus lunulatus & 22,2 & 64,5 & 83,3 & 14,3 & 66,7 & 72,2 & 33,3 & 53,3 \\
\hline Coris aygula & 27,8 & 67,7 & 16,7 & 14,3 & 0,0 & 5,6 & 0,0 & 0,0 \\
\hline Gomphosus caeruleus & 94,4 & 87,1 & 100,0 & 100,0 & 100,0 & 22,2 & 100,0 & 93,3 \\
\hline Labroides dimidiatus & 66,7 & 93,5 & 100,0 & 100,0 & 100,0 & 27,8 & 100,0 & 66,7 \\
\hline Larabicus quadrilineatus & 94,4 & 74,2 & 100,0 & 76,2 & 100,0 & 100,0 & 100,0 & 100,0 \\
\hline Novaculichthys taeniourus & 0,0 & 0,0 & 0,0 & 4,8 & 16,7 & 0,0 & 0,0 & 0,0 \\
\hline
\end{tabular}




\begin{tabular}{l|c|c|c|c|c|c|c|c}
\hline Fish species & JO 29 $^{\circ}$ & $\mathbf{E G ~ 2 7}^{\circ}$ & $\mathbf{S A ~ 2 2}^{\circ}$ & $\mathbf{S A ~ 2 1}^{\circ}$ & $\mathbf{S A ~ 2 0}^{\circ}$ & YE 15 $^{\circ}$ & $\mathbf{D J ~ 1 2}^{\circ}$ & $\mathbf{D J ~ 1 1}^{\circ}$ \\
\hline Paracheilinus octotaenia & 55,6 & 9,7 & 33,3 & 0,0 & 83,3 & 5,6 & 0,0 & 33,3 \\
\hline Thalassoma rueppellii & 100,0 & 90,3 & 83,3 & 85,7 & 83,3 & 0,0 & 0,0 & 0,0 \\
\hline Thalassoma lunare & 22,2 & 48,4 & 100,0 & 81,0 & 83,3 & 100,0 & 100,0 & 100,0 \\
\hline Acanthuridae & & & & & & & & \\
\hline Acanthurus sohal & 0,0 & 32,3 & 66,7 & 71,4 & 100,0 & 50,0 & 66,7 & 53,3 \\
\hline Naso lituratus & 5,6 & 41,9 & 50,0 & 71,4 & 50,0 & 5,6 & 0,0 & 6,7 \\
\hline Zebrasoma veliferum & 44,4 & 48,4 & 100,0 & 47,6 & 83,3 & 44,4 & 0,0 & 86,7 \\
\hline Zebrasoma xanthurum & 88,9 & 41,9 & 33,3 & 47,6 & 16,7 & 22,2 & 66,7 & 100,0 \\
\hline Balistidae & & & & & & & & \\
\hline Balistapus undulatus & 50,0 & 29,0 & 83,3 & 76,2 & 50,0 & 0,0 & 0,0 & 40,0 \\
\hline Balistoides viridescens & 0,0 & 3,2 & 33,3 & 14,3 & 16,7 & 0,0 & 0,0 & 13,3 \\
\hline Rhinecanthus assasi & 0,0 & 19,4 & 0,0 & 42,9 & 16,7 & 5,6 & 0,0 & 0,0 \\
\hline Ostraciidae & & & & & & & & \\
\hline Ostracion cubicus & 27,8 & 3,2 & 16,7 & 4,8 & 0,0 & 5,6 & 0,0 & 0,0 \\
\hline Tetraodontidae & & & & & & & & \\
\hline Arothron diadematus & 11,1 & 32,3 & 66,7 & 19,0 & 16,7 & 0,0 & 0,0 & 0,0 \\
\hline
\end{tabular}

$10 \mathrm{~m}$ deep, to 20,038 individuals per transect in Alleeth at $5 \mathrm{~m}$ deep. The meanfish abundance of all transects was 8565.8 individuals per transect. Out of the 50 species considered, only 40 were reported from this latitude, with a mean of 21.8 species per transect (Fig. 3).

In terms of relative abundance (RA), the most abundant fish species was $C$. viridis $(\mathrm{RA}=92.32 \%)$, followed by $P$. octotaenia $(\mathrm{RA}=3.86 \%)$, and $P$. sqamipinnis ( $\mathrm{RA}=$ $1.53 \%)$. These three species accounted for $97.71 \%$ of all fish species recorded from this latitude (Table 2).

In terms of frequency of appearance (FA), the most common species were $A$. sohal, C. larvatus, H. intermedius, G. caeruleus, L. dimidiatus, L. quadrilineatus, Regal angelfish Pygoplites diacanthus (Boddaert, 1772) and C. viridis (FA=100\%, each) (Table 3).

\section{Yemen}

Latitude $15^{\circ}$

A total of 129,932 fishes were counted during the 18 transects that were performed at latitude $15^{\circ}$. The mean fish abundance ranged from 95 individuals per transect at $\mathrm{Al}$ Murk at $5 \mathrm{~m}$ deep, to 24,906 individuals per transect at Quish at $4 \mathrm{~m}$ depth. The average fish abundance calculated from all transects was 7,218 individuals per transect. Of the 50 ornamental fish species considered, only 28 were reported from the Yemeni sites. The number of species observed ranged from 11 at Al-Murk ( $4 \mathrm{~m}$ depth) to 18 at both Quish and Al-Badi Island (shallow depth), with a mean of 11.1 species per transect (Fig. 3).

In terms of relative abundance (RA), the most abundant species was $C$. viridis. This species accounted for $88.5 \%$ of the fish abundance recorded at Kamaran, 79.1\% at Tekfash, 93.3\% at Quish and $85.3 \%$ at Al-Badi.

The mean relative abundance for $C$. viridis in all transects was $88.8 \%$. The second most abundant fish species was D. marginatus accounting for 4.1\%, 14.1\%, 3.1\% and $8.7 \%$ of fish abundance from Kamaran, Tekfash, Quish and Al-Badi respectively. The mean relative fish abundance for $D$. marginatus in all transects was $5.8 \%$. This was fol- 
lowed by L. quadrilineatus (average 1.6\%) and C. larvatus (average $0.8 \%$ ). These four species made up $99 \%$ of the 28 fish species which were counted (Table 2).

In terms of frequency of appearance (FA), the most common fish species were Yellowbar angelfish Pomacanthus maculosus (Forsskål, 1775), Moon Wrasse Thalassoma lunare (Linnaeus, 1758), L. quadrilineatus, and C. larvatus (100\%, each), followed by Pomacanthus asfur (Forsskål, 1775) (94.0\%) and H. intermedius (83.3\%) (Table 3).

\section{Djibouti}

Latitude $12^{\circ}$

A total of 5,368 fishes were counted in the 3 transects that were examined at latitude $12^{\circ}$. Fish abundance ranged from 1164 fishes in Gehere at $4 \mathrm{~m}$ depth, to 2408 in Gehere at $4 \mathrm{~m}$ depth. The mean fish abundance of all transects was 1789.3 individuals per transect. Of the 50 species considered, only 18 were reported from this latitude, with a mean of 13.3 species per transect (Fig 3).

In terms of relative abundance (RA), the most abundant fish species was $C$. viridis ( $\mathrm{RA}=83.8 \%)$, followed by $T$. lunare $(\mathrm{RA}=7.6 \%)$, and L. quadrilineatus $(\mathrm{RA}=4.1 \%)$. These three species accounted $95.51 \%$ of all fish species recorded from this latitude (Table 2).

In terms of frequency of appearance (FA), the most common species were C. larvatus, Arabian butterflyfish Chaetodon melapterus Guichenot, 1863, Vagaband butterflyfish Chaetodon vagabundus Linnaeus, 1758, H. intermedius, G. caeruleus, L. dimidiatus, L. quadrilineatus, T. lunare, P. maculosus, and C. viridis (100\%, each) (Table 3).

\section{Latitude $11^{\circ}$}

A total of 48,488 fishes were counted along the 15 transects that were examined in Djibouti at latitude $11^{\circ}$. Fish abundance ranged from 181 fishes in Khor Ambado at $7 \mathrm{~m}$ depth, to 16,609 in Maskali at $5 \mathrm{~m}$ depth. The mean fish abundance of all transects was 3232.5 individuals per transect. Of the 50 species considered, only 33 were reported from this latitude, with a mean of 18.8 species per transect (Fig 3).

In terms of relative abundance (RA), the most abundant fish species was $C$. viridis $(\mathrm{RA}=$ 90.81\%), followed by L. quadrilineatus $(\mathrm{RA}=1.70 \%)$, and $T$. lunare $(\mathrm{RA}=1.47 \%)($ Table 2). These three species accounted for $93.98 \%$ of all fish species recorded from this latitude.

In terms of frequency of appearance (FA), the most common species were Yellowtail tang Zebrasoma xanthurum (Blyth, 1852), C. larvatus, L. quadrilineatus and T. lunare (100\%, each), followed by C. melapterus, H. intermedius, G. caeruleus and C. viridis (93.30\%, each), see Table 3 .

\section{All Latitudes}

A total of 522,523 fish individuals were counted in the 118 transects that were examined at all latitudes (Jordan $29^{\circ}$, Egypt $27^{\circ}$, Saudi Arabia $22^{\circ}, 21^{\circ}$ and $20^{\circ}$, Yemen $15^{\circ}$, Djibouti $12^{\circ}$ and $11^{\circ}$ ). The mean fish abundance in all transects was $4428.2 \pm 87.26$ individuals per transect. 
In terms of relative abundance (RA), the most abundant fish species was $C$. viridis (RA=54.4\%), followed by P. squamipinnis $(\mathrm{RA}=34.7), D$. aruanus $(\mathrm{RA}=2.6 \%), D$. marginatus $(\mathrm{RA}=2.0)$, P. octotaenia $(\mathrm{RA}=1.0)$ and $T$. rueppellii $(0.7 \%)$. These six species accounted for $95.47 \%$ of all fish species recorded during this study (Table 2). Number of species, number of individuals, and Shannon-Wiener diversity in sites along the Jordanian, Egyptian, Saudi Arabia, Yemeni and Djiboutian reefs are shown in Figure 3. Of the 50 fish species counted during this study, the highest number of species $(S)$ was found at latitude $20^{\circ}$ on Saudi Arabian reefs $(S=21.8)$, and the lowest at latitude $15^{\circ}$ in Yemen $(S=11.11)$. The highest mean fish abundance was found on reefs at latitude $20^{\circ}$ in Saudi Arabia (8565.8), followed by latitude $15^{\circ}$ in Yemen $(A A=7218)$, whereas the lowest number of individuals was found on reefs at latitude $22^{\circ}$ in Saudi Arabia (AA= 230). The highest mean Shannon-Wiener diversity Index was found in Saudi Arabia at latitude $22^{\circ}\left(\mathrm{H}^{`}=2.4\right)$, followed latitude $29^{\circ}$ in Jordan, whereas the lowest was found at latitude $20^{\circ}$ in Saudi Arabia ( $\left.\mathrm{H}^{`}=0.6\right)$ (Fig. 3). Table 4 shows mean fish abundance for the 50 ornamental fish species at all latitudes.

\section{Fish families}

Figures 4, 5 and 6 illustrate differences in the mean fish abundance per $500 \mathrm{~m}^{2}$ transect, according to latitudinal distribution among the 50 ornamental fish species. These belong mainly to the following fish families: [Fig. 4. I. Acanthuridae (4 species), II. Balistidae (3 species), III. Chaetodontidae (14 species), IV. Pomacanthidae (4 species) [; [Fig. 5. V. Pomacentridae (5 species), VI. Pseudochromidae (3 species), VII. Cirrhitidae (one species), VIII. Serranidae (one species) IX. Labridae (11 species)]; and Fig. 6. X. Scorpaenidae (2 species), XI. Ostraciidae (one species), XII. Tetraodontidae [(one species)] that are utilized by the aquarium trade in the region.

\section{Acanthuridae (Surgeonfishes)}

Of the 12 species of surgeonfish's reported from the Red Sea, only 4 species are important in the ornamental fish trade, therefore only $A$. sohal, Orangespine unicornfish Naso lituratus (Forster, 1801 in Bloch and Schneider 1801), Z. veliferum and Z. xanthurum were counted. A. sohal were abundant along Egyptian latitude $27^{\circ}$ followed by Saudi Arabian latitude $22^{\circ}$. N. lituratus were abundant along the Djiboutian reefs at latitude $11^{\circ}$ (Fig 4). Z. veliferum were abundant along the Saudi Arabian reefs at latitudes 22 and $21^{\circ}$. Whereas, $Z$. xanthurum were most abundant along the Djiboutian reefs at latitudes 11 and $12^{\circ}$. Triggerfishes had the lowest number of individuals.

\section{Balistidae (Triggerfishes)}

This family had the lowest number of individuals of all fish families examined here. Out of the 10 triggerfishes reported from the Red Sea, only Ornage-lined triggerfish Balistapus undulatus (Park, 1797), Titan triggerfish Balistoides viridescens (Bloch \& 


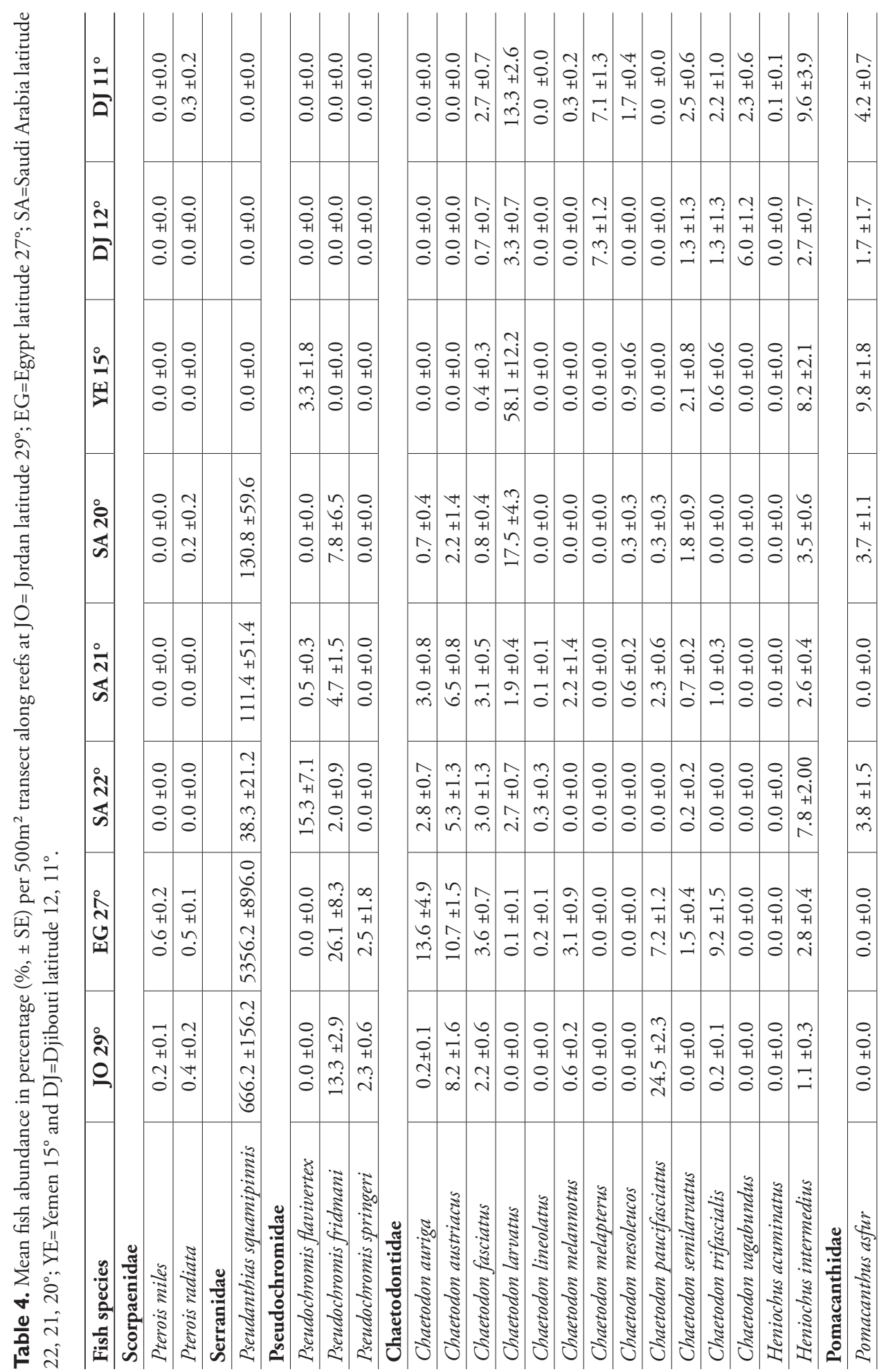




\begin{tabular}{|c|c|c|c|c|c|c|c|c|c|c|c|c|c|c|c|c|c|c|c|c|c|}
\hline & $\begin{array}{l}0 \\
\dot{0} \\
+1 \\
\dot{0} \\
\dot{0}\end{array}$ & 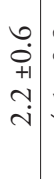 & $\begin{array}{l}\stackrel{\partial}{+} \\
+1 \\
\dot{+}+\end{array}$ & $\begin{array}{l}\hat{0} \\
+1 \\
\stackrel{+1}{n} \\
-\end{array}$ & 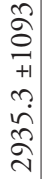 & 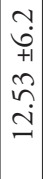 & 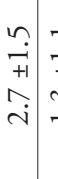 & $\begin{array}{l}\rightleftarrows \\
\stackrel{+}{+1} \\
\stackrel{-}{-}\end{array}$ & $\begin{array}{l}0 \\
\dot{0} \\
+1 \\
\stackrel{1}{0} \\
\dot{0}\end{array}$ & $\begin{array}{l}n \\
0 \\
+1 \\
0 \\
-i\end{array}$ & \begin{tabular}{c|}
0 \\
$\dot{0}$ \\
+1 \\
$\dot{0}$ \\
$\dot{0}$
\end{tabular} & $\begin{array}{c}0 \\
\dot{0} \\
+1 \\
\stackrel{1}{*}\end{array}$ & 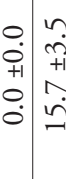 & 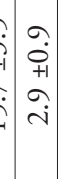 & $\left|\begin{array}{c}0 \\
0 \\
+1 \\
-1 \\
i n \\
i n\end{array}\right|$ & $\begin{array}{l}0 \\
0 \\
\dot{0} \\
+1 \\
8 \\
0 \\
\dot{0}\end{array}$ & 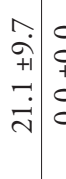 & 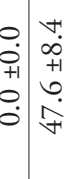 & $\begin{array}{c}\infty \\
\sim \\
\stackrel{1}{+1} \\
0 \\
\dot{n} \\
\sim\end{array}$ & $\begin{array}{l}n \\
\hat{n} \\
+1 \\
n \\
\hat{\sim}\end{array}$ & $\begin{array}{l}n \\
\underset{+}{+1} \\
\dot{+} \\
\dot{0}\end{array}$ \\
\hline$\frac{\stackrel{\overbrace{}}{7}}{\bar{a}}$ & $\begin{array}{l}\text { ? } \\
+ \\
+1 \\
? \\
0\end{array}$ & $\begin{array}{c}0 \\
\dot{0} \\
+1 \\
0 \\
i\end{array}$ & $\begin{array}{l}0 \\
\dot{0} \\
+1 \\
0 \\
\dot{0}\end{array}$ & $\mid \begin{array}{c}0 \\
\dot{0} \\
+1 \\
0 \\
0 \\
0\end{array}$ & 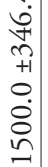 & $\begin{array}{c}0 \\
\dot{0} \\
+1 \\
0 \\
\dot{0}\end{array}$ & $\begin{array}{ll}0 \\
\dot{0} \\
+1 \\
0 \\
0\end{array}$ & $\begin{array}{l}0 \\
\dot{0} \\
+1 \\
0 \\
\dot{0}\end{array}$ & $\begin{array}{l}0 \\
\dot{0} \\
+1 \\
0 \\
\dot{0}\end{array}$ & $\begin{array}{l}0 \\
\dot{0} \\
+1 \\
0 \\
\dot{0}\end{array}$ & $\begin{array}{l}0 \\
\dot{0} \\
+1 \\
0 \\
\dot{0}\end{array}$ & $\begin{array}{c}n \\
0 \\
+1 \\
n \\
0\end{array}$ & 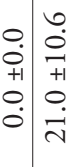 & 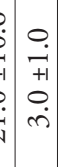 & 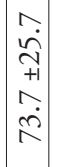 & $\begin{array}{c}0 \\
0 \\
\dot{0} \\
+1 \\
8 \\
\dot{0} \\
\dot{0}\end{array}$ & \begin{tabular}{c|c}
0 & 0 \\
$\dot{0}$ & 0 \\
+1 & + \\
0 & 0 \\
0 & 0
\end{tabular} & 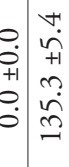 & $\begin{array}{c}\sim \\
+ \\
+1 \\
0 \\
\infty \\
\infty\end{array}$ & $\begin{array}{l}0 \\
\dot{0} \\
+1 \\
0 \\
0\end{array}$ & $\begin{array}{l}0 \\
\dot{0} \\
+1 \\
0 \\
0 \\
\dot{0}\end{array}$ \\
\hline $\begin{array}{l}\text { in } \\
\text { 픽 }\end{array}$ & $\begin{array}{c}-1 \\
\dot{0} \\
+1 \\
-\dot{0}\end{array}$ & 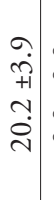 & $\begin{array}{l}0 \\
\dot{0} \\
+1 \\
0 \\
\dot{0}\end{array}$ & $\begin{array}{c}- \\
\dot{0} \\
+1 \\
-1 \\
\dot{0}\end{array}$ & 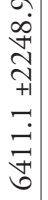 & $\begin{array}{c}\infty \\
\stackrel{\infty}{\sim} \\
\stackrel{+1}{+1} \\
0 \\
\stackrel{+}{\sim} \\
\sim\end{array}$ & 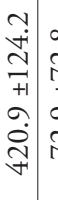 & 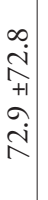 & $\begin{array}{l}0 \\
0 \\
+1 \\
0 \\
0 \\
\dot{+}\end{array}$ & $\begin{array}{l}0 \\
\dot{0} \\
+1 \\
\stackrel{1}{0} \\
\dot{0}\end{array}$ & $\begin{array}{c}0 \\
\dot{0} \\
+1 \\
\vdots \\
\dot{0}\end{array}$ & \begin{tabular}{c|c}
$\overrightarrow{0}$ & \\
+1 \\
$\sim$ \\
$\sim$ \\
\end{tabular} & 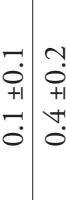 & 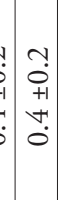 & $\begin{array}{c}\tilde{\Xi} \\
\vec{\tau} \\
+1 \\
\underline{\Xi} \\
\dot{ \pm} \\
\Xi\end{array}$ & $\mid \begin{array}{c}0 \\
8 \\
\dot{0} \\
+1 \\
\dot{1} \\
\dot{0} \\
\dot{0}\end{array}$ & \begin{tabular}{l|l}
0 & 0 \\
$\dot{n}$ & \\
+1 & + \\
$\dot{n}$ & \\
$\dot{n}$ &
\end{tabular} & 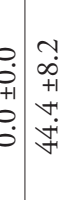 & $\begin{array}{c}n \\
n \\
+1 \\
\infty \\
0 \\
0 \\
-1\end{array}$ & 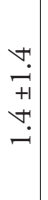 & 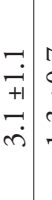 \\
\hline 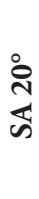 & 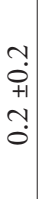 & $\begin{array}{l}n \\
0 \\
+1 \\
\hat{-1}\end{array}$ & $\begin{array}{l}m \\
0 \\
+1 \\
\tilde{i} \\
\stackrel{+}{i}\end{array}$ & $\begin{array}{c}0 \\
0 \\
+1 \\
\\
\stackrel{-}{-}\end{array}$ & 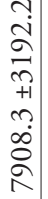 & $\begin{array}{l}\infty \\
+ \\
+1 \\
n \\
0 \\
0\end{array}$ & 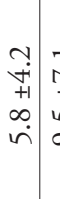 & $\begin{array}{l}\check{\sim} \\
+1 \\
\sim \\
\tilde{\sigma}\end{array}$ & 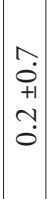 & 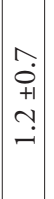 & $\begin{array}{c}\infty \\
\dot{0} \\
+1 \\
\infty \\
0 \\
\dot{0}\end{array}$ & \begin{tabular}{c|c}
0 \\
$\dot{+}$ \\
+1 \\
$\sim$ \\
\end{tabular} & 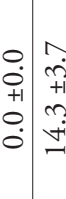 & 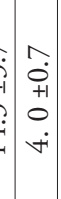 & $\left|\begin{array}{c}n \\
\dot{+} \\
+1 \\
\infty \\
\dot{m} \\
m\end{array}\right|$ & $\begin{array}{l}1 \\
\stackrel{+}{0} \\
+1 \\
\stackrel{1}{0} \\
\dot{0}\end{array}$ & 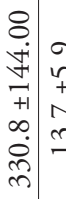 & 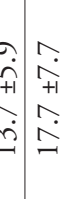 & $\begin{array}{c}n \\
\infty \\
+1 \\
n \\
\tilde{b} \\
\sim \\
\sim\end{array}$ & 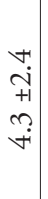 & 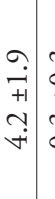 \\
\hline$\frac{\stackrel{0}{\pi}}{\sqrt{n}}$ & $\begin{array}{l}0 \\
\dot{0} \\
+1 \\
0 \\
\dot{0}\end{array}$ & $\begin{array}{c}\Downarrow \\
\vdots \\
0 \\
+1 \\
+ \\
0 \\
0\end{array}$ & $\begin{array}{l}\infty \\
\stackrel{0}{+} \\
+1 \\
\\
\stackrel{+}{+}\end{array}$ & $\begin{array}{l}n \\
0 \\
+1 \\
\sim \\
-1\end{array}$ & 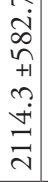 & $\mid$\begin{tabular}{c}
$m$ \\
$\sim$ \\
$\infty$ \\
\hdashline \\
+1 \\
0 \\
$\dot{+}$ \\
$\stackrel{2}{+}$
\end{tabular} & $\begin{array}{lll}0 & \\
0 & 1 \\
+1 & \\
0 & 1 \\
0 & \end{array}$ & $\begin{array}{c}\sim \\
\\
\\
\end{array}$ & $\begin{array}{l}\tilde{1} \\
+1 \\
\approx \\
\approx\end{array}$ & $\begin{array}{c}\dot{0} \\
\dot{0} \\
+1 \\
\stackrel{+}{v}\end{array}$ & $\begin{array}{l}ت \\
0 \\
+1 \\
\sim \\
0 \\
0\end{array}$ & $\begin{array}{c}n \\
\stackrel{0}{0} \\
+1 \\
+ \\
\dot{0}\end{array}$ & 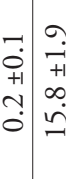 & 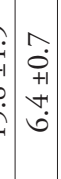 & $\begin{array}{c}\Im \\
+1 \\
+1 \\
0 \\
\dot{0}\end{array}$ & 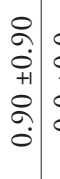 & \begin{tabular}{l|l}
0 & 0 \\
$\dot{0}$ & m \\
+1 & + \\
0 & $\alpha$ \\
0 & 9
\end{tabular} & 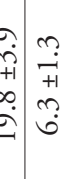 & $\begin{array}{l}\infty \\
\dot{a} \\
+1 \\
\varrho \\
\infty \\
\infty\end{array}$ & $\begin{array}{c}\sigma \\
\dot{0} \\
+1 \\
-\dot{+}\end{array}$ & $\begin{array}{l}n \\
\stackrel{9}{+1} \\
8 \\
\vdots \\
\dot{\theta}\end{array}$ \\
\hline ঙัণ & $\begin{array}{l}0 \\
0 \\
+1 \\
0 \\
0\end{array}$ & $\begin{array}{l}\simeq \\
0 \\
+1 \\
\sim \\
\end{array}$ & $\begin{array}{c}\infty \\
\dot{0} \\
+1 \\
\sim \\
\\
\end{array}$ & $\begin{array}{l}n \\
0 \\
+1 \\
\infty \\
0\end{array}$ & $\begin{array}{c}0 \\
\dot{0} \\
+1 \\
0 \\
\dot{0}\end{array}$ & $\mid \begin{array}{l}\stackrel{\sigma}{0} \\
+1 \\
\stackrel{+1}{-}\end{array}$ & \begin{tabular}{l|c}
0 & \\
0 & \\
+1 & \\
0 & 0 \\
0 &
\end{tabular} & $\begin{array}{c}0 \\
0 \\
+1 \\
0 \\
0\end{array}$ & 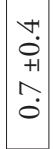 & $\begin{array}{l}\infty \\
\dot{0} \\
+1 \\
\sim \\
\end{array}$ & 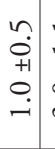 & 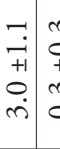 & 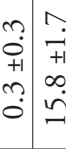 & 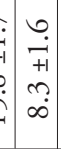 & 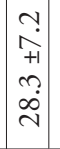 & 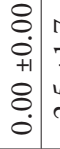 & 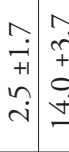 & 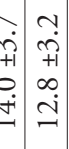 & $\begin{array}{l}\tilde{n} \\
\tilde{n} \\
+1 \\
\tilde{n} \\
\infty \\
\sim \\
\sim\end{array}$ & $\begin{array}{l}- \\
\stackrel{+}{+} \\
+1 \\
\stackrel{+}{0}\end{array}$ & $\begin{array}{l}n \\
\infty \\
\infty \\
+1 \\
\infty \\
\dot{t} \\
-1\end{array}$ \\
\hline 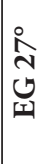 & $\begin{array}{c}-1 \\
0 \\
+1 \\
n \\
0\end{array}$ & $\begin{array}{c}-1 \\
0 \\
+1 \\
+ \\
+ \\
0\end{array}$ & $\begin{array}{l}m \\
0 \\
+1 \\
n \\
n\end{array}$ & $\begin{array}{c}+ \\
i+1 \\
+1 \\
\infty \\
i \\
\sim\end{array}$ & 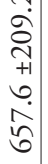 & $\begin{array}{c}8 \\
\dot{0} \\
\dot{+} \\
+1 \\
\hat{\sim} \\
\dot{0}\end{array}$ & $\begin{array}{l}\infty \\
\stackrel{1}{+1} \\
\stackrel{1}{+} \\
\stackrel{-}{-}\end{array}$ & $\begin{array}{l}\forall \\
\dot{0} \\
+1 \\
\infty \\
\dot{0}\end{array}$ & 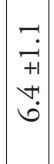 & $\begin{array}{c}- \\
\stackrel{+}{+1} \\
0 \\
\end{array}$ & $\begin{array}{c}0 \\
\vdots \\
0 \\
+1 \\
ٌ \\
-\end{array}$ & 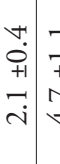 & 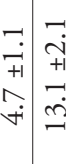 & 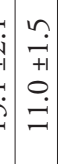 & $\begin{array}{c}\hat{y} \\
\dot{+} \\
+1 \\
\hat{n}\end{array}$ & $\mid \begin{array}{c}8 \\
\dot{0} \\
\dot{0} \\
+1 \\
8 \\
\dot{0} \\
\dot{0}\end{array}$ & 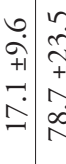 & 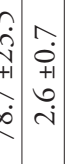 & 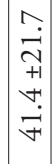 & 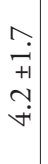 & 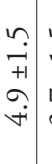 \\
\hline 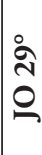 & $\begin{array}{c}\breve{1} \\
0 \\
+1 \\
-1 \\
0\end{array}$ & $\begin{array}{l}0 \\
\dot{0} \\
+1 \\
0 \\
\dot{0}\end{array}$ & 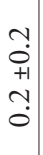 & $\begin{array}{c}0 \\
i \\
+1 \\
\sim \\
\sim \\
\sim \\
\sim\end{array}$ & 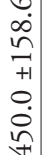 & 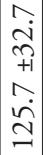 & 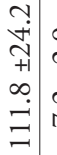 & 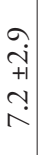 & $\begin{array}{l}0 \\
\dot{0} \\
+1 \\
0 \\
\dot{0}\end{array}$ & $\begin{array}{c}\curvearrowright \\
\dot{+1} \\
+1 \\
\infty \\
\sigma\end{array}$ & $\begin{array}{c}0 \\
\dot{0} \\
+1 \\
0 \\
\dot{i}\end{array}$ & 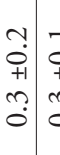 & 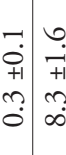 & 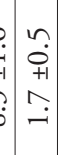 & $\begin{array}{c}- \\
\dot{+1} \\
\infty \\
0 \\
0\end{array}$ & \begin{tabular}{l|l}
8 \\
$\vdots$ \\
+1 \\
+1 \\
$\vdots$ \\
0
\end{tabular} & 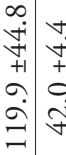 & 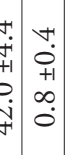 & $\begin{array}{l}0 \\
\dot{0} \\
+1 \\
0 \\
0\end{array}$ & $\begin{array}{c}ت \\
\dot{0} \\
+1 \\
-1 \\
0\end{array}$ & $\begin{array}{c}n \\
0 \\
+1 \\
\beth \\
-\end{array}$ \\
\hline
\end{tabular}

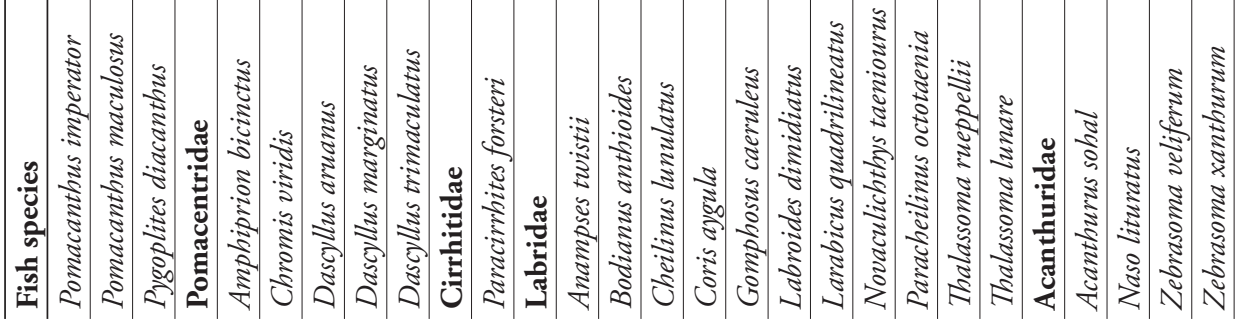




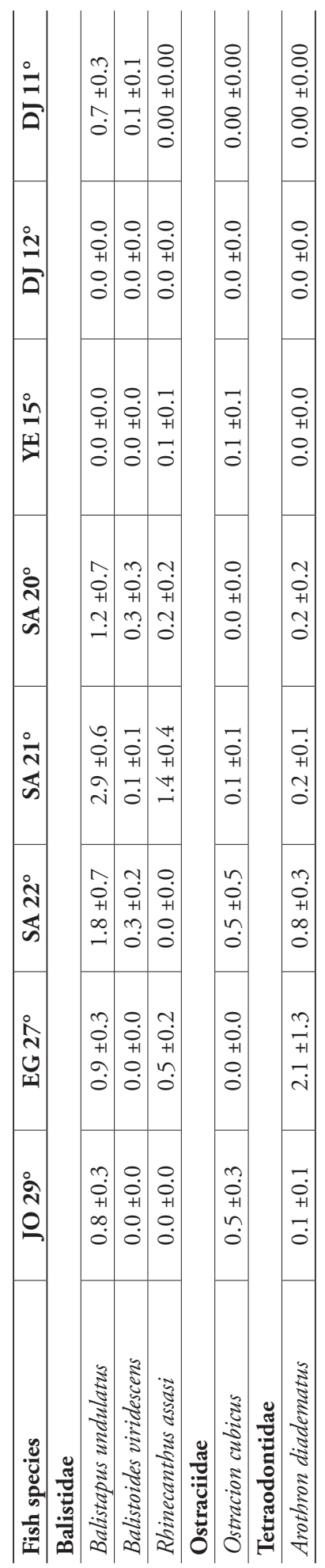




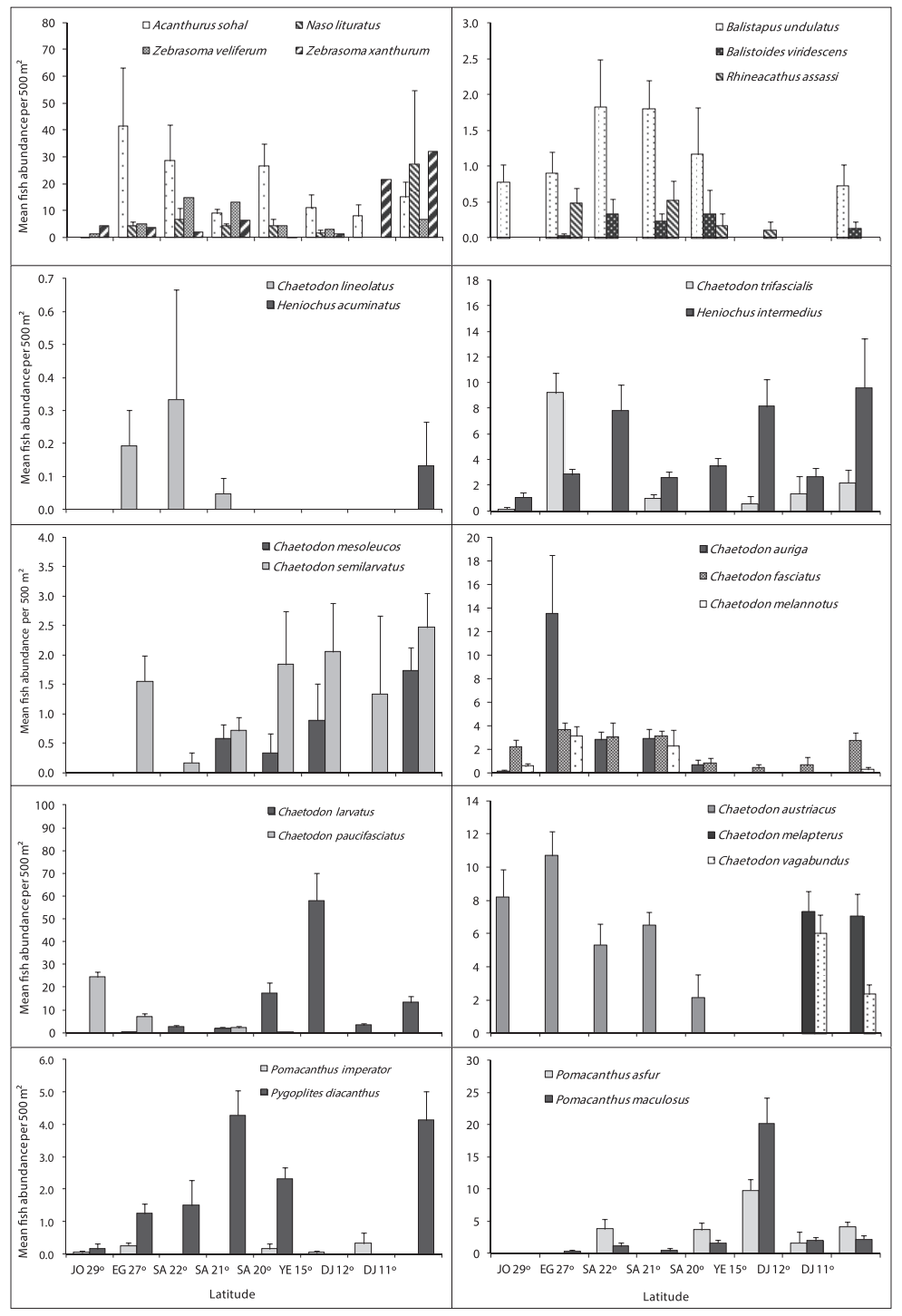

Figure 4. Differences in mean fish abundance per $500 \mathrm{~m}^{2}$ transect according to latitudinal distribution for the families: Acanthuridae (A. sohal, N. lituratus, Z. veliferum and Z. xanthurum), Balistidae (B. undulates, $B$. viridescens, and $R$. assassin), Chaetodontidae (C. lineolatus, H. acuminatus, $C$. mesoleucos, $C$. semilarvatus, $C$. auriga, C. fasciatus, C. melannotus, C. larvatus, C. paucifasciatus, C. austiacus, C. trifascialis, H. intermedius, C. melapterus, and C. vagabundus), and Pomacanthidae (P. asfur, P. imperator, P. maculosus and P. diacanthus).

Schneider, 1801), and Picasso triggerfish Rhinecanthus assasi (Forsskål, 1775) were counted due to their importance in the aquarium trade. Geographical trends indicated that $B$. undulates and $B$. viridescens were more abundant along the Saudi Arabian reefs at Latiudes 22,21 and $20^{\circ}$ but $R$. assassi did not show any clear geographical trend (Fig. 4). 


\section{Chaetodontidae (Butterflyfishes)}

Out of the 17 butterflyfishes known from the Red Sea, this study indicates the presence of 14 species. Geographical trends were observed in almost all butterflyfish species (Fig. 4). C. austiacus and C. paucifasciatus were most abundant along the reefs at latitudes 29 and $27^{\circ}$. These two species were not recorded in latitudes 15,12 and $11^{\circ}$. On the other hand, C. auriga, C. fasciatus and Chaetodon lineolatus Cuvier, 1831 in Cuvier and Valenciennes were most abundant along the Egyptian and Saudi Arabia at latitudes 27, 22, and $21^{\circ}$. C. larvatus was most abundant along the Saudi Arabia and Yemen reefs at latitudes 20 and $15^{\circ}$. There were 3 butterflyfish species $C$. melapterus, $C$. vagabundus, and Pennant coralfish Heniochus acuminatus (Linnaeus, 1758) exist only at the Djiboutian reefs at latitudes 12 and $11^{\circ}$. The distributional pattern for all butterflyfish species is shown in Fig. 4.

\section{Pomacanthidae (Angelfishes)}

This family had the second lowest number of individuals of the fish families examined here. Out of the 7 species of angelfish recorded from the Red Sea, only 4 species (P. asfur, Emperor angelfish, Pomacanthus imperator (Bloch, 1787), P. maculosus, and $P$. diacanthus) that are used in the aquarium fish trade in the Red Sea were found. Latitude $15^{\circ}$ exhibited the highest number of individuals for angelfish species, particularly for $P$. asfur and P. maculosus. Whereas, the reefs at the latitude $29^{\circ}$ had the lowest number of individuals. Geographical trends were clear for some species like $P$. asfur which is the most abundant angelfish at the latitudes $15^{\circ}$ but did not reach the northern Red Sea at the reefs between latitudes 29 and $27^{\circ}$. The distributional pattern for angelfish species is shown in Fig. 4.

\section{Psudochromidae (Dottybacks)}

Out of the 12 dottybacks fishes known from the Red Sea, only 3 species of importance in ornamental fish trade were counted. The 3 of them were not reported along the Djiboutian reefs. Bluestriped dottyback Pseudochromis springeri Lubbock, 1975 preferred the north, and it was found only along the Jordanian and Egyptian reefs at latitudes 29 and $27^{\circ}$. Whereas, Orchid dottyback Pseudochromis fridmani Klausewitz, 1968 extended to reach reefs at latitude $15^{\circ}$. The distributional pattern for Dottybacks is shown in Fig. 4.

\section{Pomacentridae (Damselfishes)}

Damselfishes had the highest number of individuals at all studied sites. Out of 35 damselfishes known from the Red Sea, only 5 species that are mostly used in the aquarium trade in the region were counted. C. viridis was the most dominant species of the damselfish family on Red Sea reefs. Geographical distribution of the clownfish A. bicinctus revealed that it prefers the Jordanian and Egyptian reefs at latitude $29^{\circ}$ and $27^{\circ}$. The distributional pattern for damselfishes is shown in Fig. 5. 


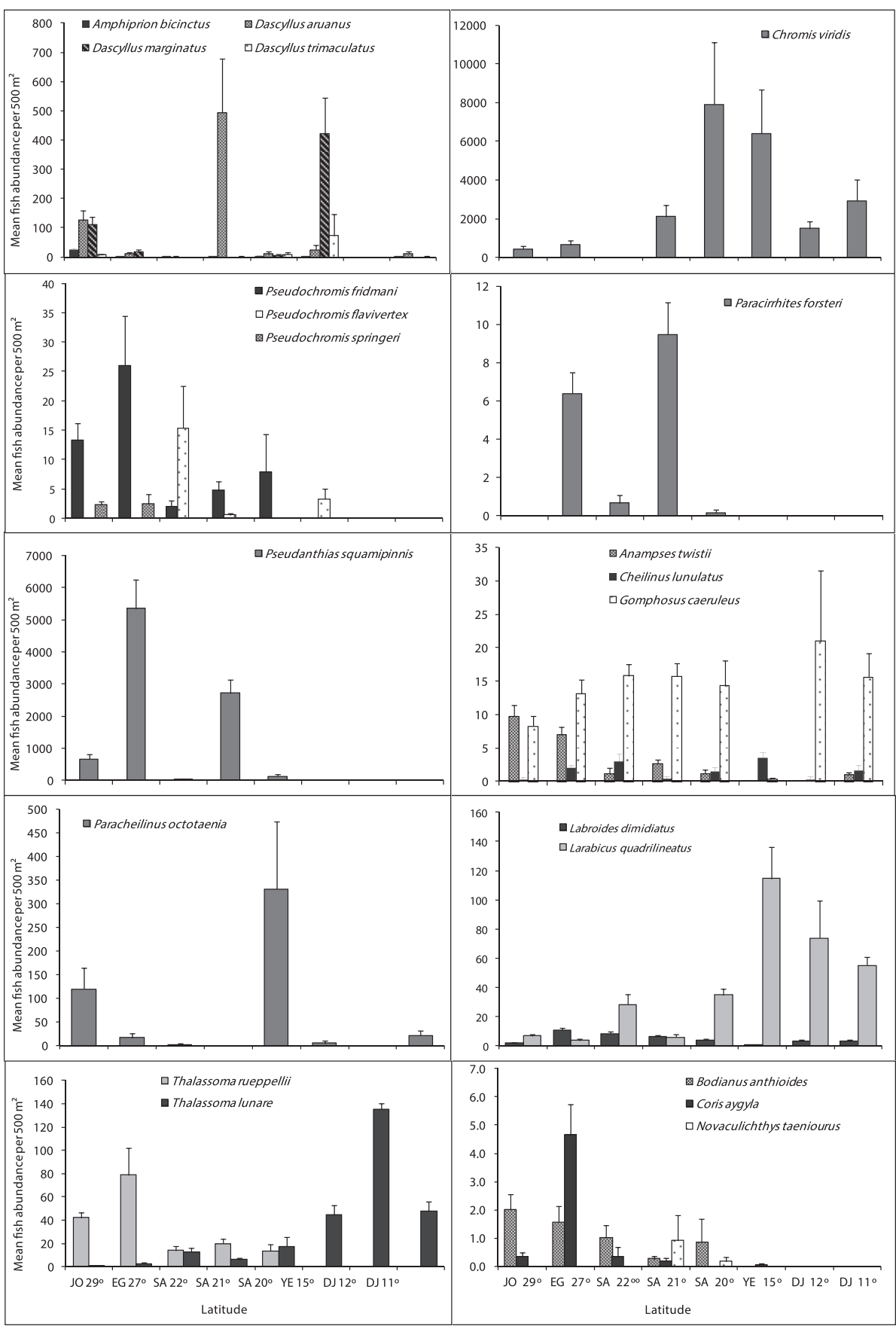

Figure 5. Differences in mean fish abundance per $500 \mathrm{~m}^{2}$ transect according to latitudinal distribution for the fish species belonging mainly to families: Pomacentridae (A. bicinctus, D. aruanus, D. marginatus, D. trimaculatus, and C. viridis), Pseudochromidae (P. fridmani, P. flavivertex and P. springeri), Cirrhitidae (P. forsteri), Serranidae (P. squamipinnis), and Labridae (A. twistii, C. lunulatus, G. caeruleus, P. octotaenia, L. dimidiatus, L. qudrilineatus, T. rueppellii, T. lunare, B. anthioides, C. aygula and N. taeniourus). 


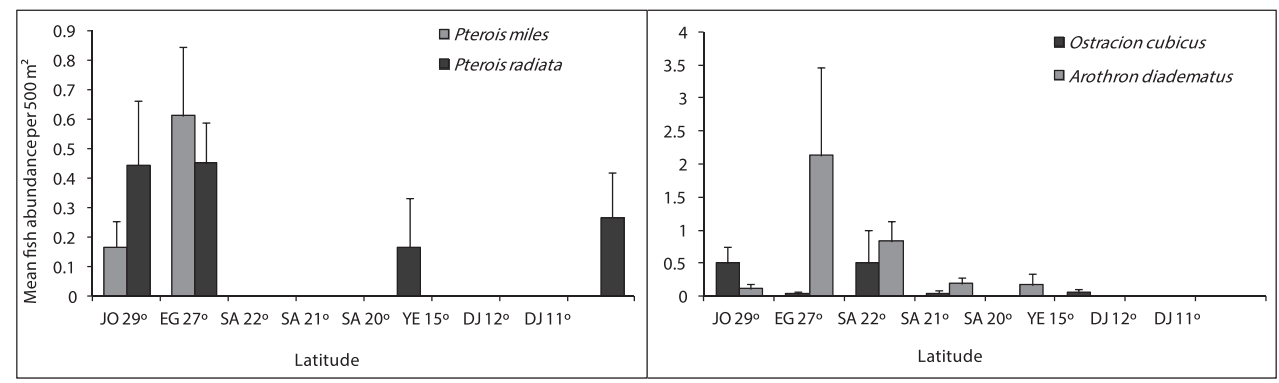

Figure 6. Differences in mean fish abundance per $500 \mathrm{~m}^{2}$ transect according to latitudinal distribution for the fish species belonging to the family Scorpaeinidae (P. miles, P. radiata), Ostraciidae (O. cubicus), and Tetraodontidae (A. diadematus).

\section{Labridae (Wrasses)}

Out of the 64 wrasses reported from the Red Sea, only 11 species that are used mostly in the aquarium fish trade were counted. T. rueppellii, Bodianus anthioides (Bennett, 1832), Coris aygula Lacepède, 1801 and $A$. twistii were most abundant along the reefs in latitudes 29 and $27^{\circ}$; they were rare or not recorded along the Yemeni and Djiboutian reefs at latitudes 15,12 and $11^{\circ}$. However, T. rueppellii and B. anthioides were restricted to the northern and central Red Sea. On the other hand, T. lunare was most abundant in the south at latitudes 15,12 and $11^{\circ}$. The cleaner wrasse L. dimidiatus was most abundant along the reefs in latitudes $27,22^{\circ}$ and L. qudrilineatus on the other side was most abundant along the reefs at latitudes 15,12 and $11^{\circ}$. The distributional pattern for wrasses is presented in Fig. 5.

\section{Serranidae (Groupers)}

Only $P$. squampinnis belonging to the subfamily Anthininae was counted during this study. The counts indicated that this species was most abundant along the reefs at latitudes 27 and $29^{\circ}$ respectively and it was not reported from the Yemeni and Djiboutian reefs at latitudes 15,12 and $11^{\circ}$ (Fig. 5).

\section{Cirrhitidae (Hawkfishes)}

P. forsteri did not show a geographical trend in its distribution, except that it was not recorded in reefs at latitudes $29^{\circ}, 15,12$ and $11^{\circ}$ (Fig. 5).

\section{Ostracidae (Boxfishes)}

The distributional patterns for the boxfish, Ostracion cubicus Linnaeus, 1758, are shown in Fig. 6. It was abundant along the Jordanian reefs at latitude $29^{\circ}$ and Saudi Arabia $22^{\circ}$ reefs. It was either rare or not reported in other studied sites. 


\section{Tetraodontidae (Pufferfishes)}

Arothron diadematus (Rüppell, 1829) is of importance in the fish aquarium trade in the region, and the number of individuals were very low. This species was not reported in the southern Red Sea and Gulf of Aden (Fig. 6).

\section{Scorpaenidae (Scorpionfishes)}

Two species Pterois miles (Bennett, 1828) and Pterois radiata Cuvier, 1829 in Cuvier and Valenciennes 1829 belonging to this family were counted; Pterois miles was reported only on Jordanian and Egyptian reefs. Whereas, $P$. radiata reached to Djiboutian waters, but both species were present in very low numbers. The distributional pattern for both species is shown in Fig. 6.

\section{Correlation of fish community pattern with benthic habitat}

The simple regression procedure of the Stat View software was used to correlate the fish community patterns such as species richness, average fish abundance $(\mathrm{N})$, and Shannon-Wiener Index $\left(\mathrm{H}^{\prime}\right)$ to benthic habitat (Table 5). The maximum regression correlation between hard coral cover and fish species richness $(\mathrm{r}=0.9060)$ was at reefs in latitude $12^{\circ}$ followed by latitude $22^{\circ}$. Whereas, the strongest correlation with average fish abundance $(\mathrm{r}=0.554)$ was at reefs in latitude $20^{\circ}$, followed by latitude $15^{\circ}$. Reefs in latitude $20^{\circ}$ also exhibited the highest regression correlation with Shannon-Wiener

Table 5. Regression correlation ( $\mathrm{r}$ ) analysis of fish community pattern vs. hard coral (simple regression); mean fish abundance $(\mathrm{N})$, species richness (number of species) and Shannon-Wiener Index $\left(\mathrm{H}^{\circ}\right)$ at reefs at various latitudes along the Red Sea and Gulf of Aden * if $p<0.05$ significant correlation.

\begin{tabular}{|c|c|c|c|}
\hline Latitude & Number of species & Number of Individuals & Shannon-Wiener diversity $\mathbf{H}^{\prime}$ \\
\hline \multirow{2}{*}{$29^{\circ}$} & 0,257 & $\mathbf{0 , 3 7 8}$ & 0,219 \\
\hline & $p=0.305$ & $p=0.121$ & $\mathrm{p}=0.385$ \\
\hline \multirow{2}{*}{$27^{\circ}$} & 0,395 & 0,354 & 0,451 \\
\hline & $p=0.028^{*}$ & $p=0.051$ & $p=0.01^{*}$ \\
\hline \multirow{2}{*}{$22^{\circ}$} & 0,179 & 0,473 & 0,118 \\
\hline & $p=0.733$ & $p=0.343$ & $p=0.807$ \\
\hline \multirow{2}{*}{$21^{\circ}$} & 0,415 & 0,447 & 0,2 \\
\hline & $p=0.613$ & $p=0.042 *$ & $p=0.385$ \\
\hline \multirow{2}{*}{$20^{\circ}$} & 0,767 & 0,554 & 0,758 \\
\hline & $p=0.075$ & $p=0.254$ & $p=0.080$ \\
\hline \multirow{2}{*}{$15^{\circ}$} & 0,663 & 0,221 & 0,584 \\
\hline & $p=0.003^{*}$ & $p=0.375$ & $p=0.011$ \\
\hline \multirow{2}{*}{$12^{\circ}$} & 0,906 & 0,431 & 0,448 \\
\hline & $p=0.278$ & $p=0.716$ & $p=0.711$ \\
\hline \multirow{2}{*}{$11^{\circ}$} & 0,02 & 0,305 & $\mathbf{0 , 0 7 1}$ \\
\hline & $p=0.944$ & $p=0.268$ & $p=0.793$ \\
\hline
\end{tabular}


Table 6. Regression correlation ( $\mathrm{r}$ ) analysis of fish community pattern vs. soft coral (simple regression); mean fish abundance $(\mathrm{N})$, species richness (number of species) and Shannon-Wiener Index $\left(\mathrm{H}^{\circ}\right)$ at reefs at various latitudes along the Red Sea and Gulf of Aden. * if $p<0.05$ significant correlation.

\begin{tabular}{c|c|c|c}
\hline Latitude & Number of species & Number of Individuals & Shannon-Wiener diversity $\mathbf{H}^{\prime}$ \\
\hline $\mathbf{2 9 ^ { \circ }}$ & $\mathbf{0 , 3 2 9}$ & $\mathbf{0 , 3 1 1}$ & $\mathbf{0 , 4 4 5}$ \\
\hline & $p=0.183$ & $p=0.209$ & $p=0.064$ \\
\hline $\mathbf{2 7 ^ { \circ }}$ & $\mathbf{0 , 1 2 2}$ & $\mathbf{0 , 3 5 5}$ & $\mathbf{0 , 5 6 4}$ \\
\hline & $p=0.509$ & $p=0.050^{*}$ & $p=0.001^{*}$ \\
\hline $\mathbf{2 2}^{\circ}$ & $\mathbf{0 , 3 3 8}$ & $\mathbf{0 , 2 7 6}$ & $\mathbf{0 , 4 8 4}$ \\
\hline & $p=0.513$ & $p=0.598$ & $p=0.330$ \\
\hline $\mathbf{2 1}^{\circ}$ & $\mathbf{0 , 3 4 2}$ & $\mathbf{0 , 4 7 5}$ & $\mathbf{0 , 4 2 2}$ \\
\hline & $p=0.128$ & $p=0.030$ & $p=0.0 .056$ \\
\hline $\mathbf{2 0 ^ { \circ }}$ & $\mathbf{0 , 2 3 7}$ & $\mathbf{0 , 0 9 5}$ & $\mathbf{0 , 7 5 8}$ \\
\hline & $p=0.650$ & $p=0.862$ & $p=0.897$ \\
\hline $\mathbf{1 5}^{\circ}$ & $\mathbf{0}$ & $\mathbf{0}$ & $\mathbf{0}$ \\
\hline & $p=1.000$ & $p=1.000$ & $p=1.000$ \\
\hline $\mathbf{1 2}^{\circ}$ & $\mathbf{0 , 1 9}$ & $\mathbf{0 , 9 8 4}$ & $\mathbf{0 , 9 9}$ \\
\hline & $p=0.880$ & $p=0.115$ & $p=0.120$ \\
\hline $\mathbf{1 1}^{\circ}$ & $\mathbf{0 , 3 3 6}$ & $\mathbf{0 , 1 1 4}$ & $\mathbf{0 , 3 3}$ \\
\hline & $p=0.220$ & $p=0.685$ & $p=0.229$ \\
\hline
\end{tabular}

diversity ( $\mathrm{r}=0.7582$ ), followed by latitude $15^{\circ}$ (Table 5 ). However, the highest correlation between soft coral and species richness was $(\mathrm{r}=0.3420)$ at latitude $21^{\circ}$, followed by latitude $22^{\circ}$ (Table 6 ). Whereas, the maximum regression correlation with average fish abundance was found $(\mathrm{r}=0.9838)$ at latitude $12^{\circ}$, followed by latitude $21^{\circ}$. Reefs at Latitude $12^{\circ}$ exhibited the highest regression correlation with Shannon-Wiener diversity $(\mathrm{r}=0.9869)$, followed by latitude $20^{\circ}$.

\section{Biogeography}

Cluster analysis revealed that two primary groups of sites can be distinguished from the data (Fig. 7): Group A is divided into two sub-groups gathering the sites from Djibouti and Yemen with about 58\% similarity: sub-group (A1) incorporates sites in Djibouti latitudes 12 and $11^{\circ}$ with about $70 \%$ similarity (A2) incorporates sites in the country of Yemen (latitude $15^{\circ}$ ) with about $63 \%$ similarity, and sub-group. Group (B) is divided into 3 sub-groups gathering the sites in Jordan, Egypt and Saudi Arabiawith $71 \%$ similarity: subgroup (B1) incorporates the sites in Jordan latitude $\left(29^{\circ}\right)$ with about 82\% similarity, subgroup (B2) incorporates most of the sites in Egypt at latitudes 27 and some sites in Saudi Arabia at latitudes (20, and $21^{\circ}$ ) with about $82 \%$ similarity.,and subgroup (B3) incorporates the sites is Saudi Arabia at latitudes (21 and $22^{\circ}$ ) with about $75 \%$ similarity. These two main groups (A and B) are connected together with about $52 \%$ similarity. The data clearly show that ornamental fish communities in the Red Sea and Gulf of Aden fall into two distinct biogeographical groups. 


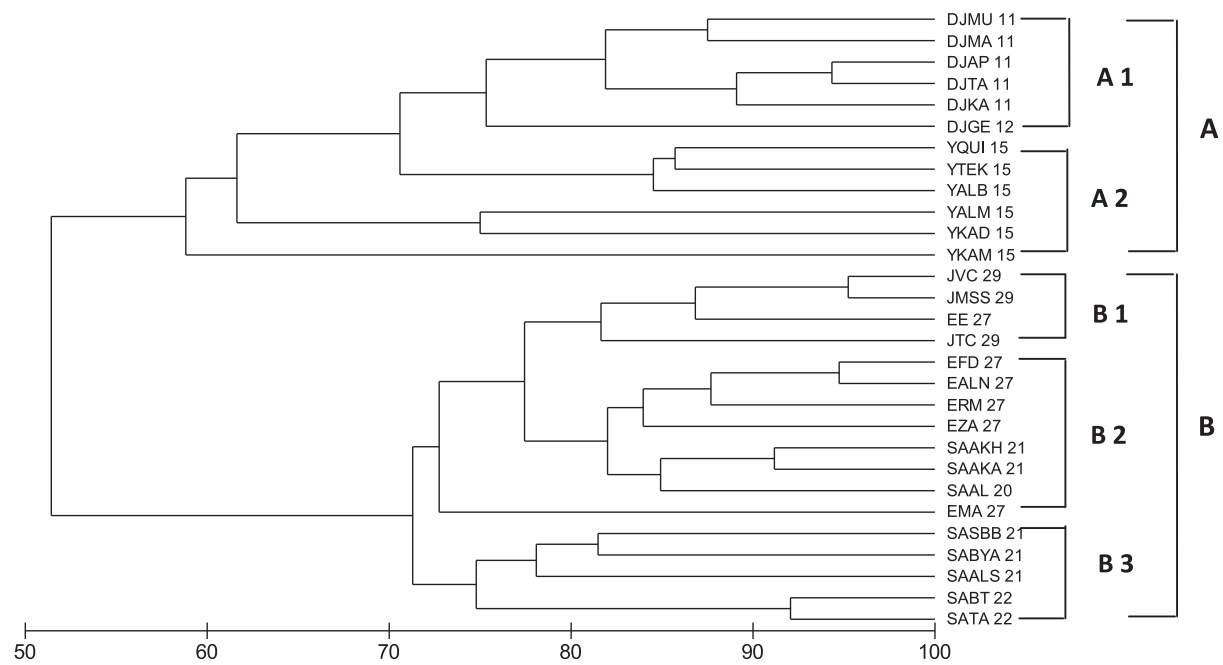

Figure 7. Cluster analysis of relationships between ornamental fish assemblages (Bray-Curtis similarity) from different countries in the Red Sea and Gulf of Aden region. Country Key: J29 $9^{\circ}$ sites at latitude at $29^{\circ}$ on the Jordanian coast, JMSS 29= Marine Science Station, JTC 29= Tourist Camp, JVC= Visitor Center; $\mathrm{E} 27^{\circ}=$ sites at latitude $27^{\circ}$ in Egypt, EALN 27 $=$ AL-Noksh, EMA 27= Mahmoudat, EFD 27= Fanar Dolphin, EE 27= Elli, ERM 27= Ras Mohamad, EZA 27= Zorab; SA22, SA21 and SA20 $=$ sites at latitudes on the Saudi Arabia coast, SATA 22= Thoal - Awjam, SABT 22= Bostek/Thoal, SAAKA $21=$ Alkabeera, SABYA 21= Bayada, SASBB 21= South Batch Bayada, SAALS 21= Al-Sagheera, SAAKH $21=$ Al-Kherq, SAAL 20 $=$ Alleeth; $\mathrm{Y}^{\circ} 5^{\circ}=$ sites at latitude along the Yemeni coast, YKAD 15= Kadaman, YKAM 15= Kamaran, YTEK 15= Tekfash, YQUI 15= Quish, YALM 15= Al-murk, YALB 15= Al-Badi; Dj11 and Dj1 $2^{\circ}=$ sites at latitudes 11 and $12^{\circ}$ along the Djiboutian coast, DJGE $12=$ Gehere, DJKA $11=$ Khor Ambado, DJMA 11= Maskali, DJMU 11= Musha, DJTA 11= Tajoura, DJAP 11= ArtaPlaga

One of the groups characterizes the northern and central Red Sea, whilst the other is in the southern Red Sea and Gulf of Aden.

\section{Discussion}

A new and updated checklist of fishes of the Red Sea has recorded a total of 1078 species belonging to 154 families (Golani and Bogorodsky 2010). From this list, a total of 50 fish species used for aquarium trade were investigated during the present study. A database for aquarium fish stocks was established during this intensive survey, and is housed at PERSGA office Jeddah, Saudi Arabia.

This study revealed marked differences in the structure of ornamental fish assemblages with latitude. The presence-absence data for the fifty ornamental fish species used in the aquarium trade in the region support the presence of two main biogeographic gradients in the Red Sea and Gulf of Aden: a south Red Sea and Gulf of Aden latitudinal gradient, and a gradient along the north and central Red Sea. Latitudinal gradients in water quality (temperature, salinity, plankton production) may cause in part this 
north-south variation in fish community structure. There are marked changes in the structure of coral reef fish communities moving from north to the south within the Red Sea. Carter and Prince (1981) concluded that gradual changes in salinity and temperature could generate abrupt boundaries for species distributions. Differences in environmental tolerance among species could mean that some are better adapted to conditions prevailing in the south than those further north or vice-versa. Factors in the physical environment including irradiance, salinity, temperature, pressure, nutrients and wastes all influence the distribution of organisms in the sea. The ability of an organism to tolerate changes in these physical environmental factors plays a major role in determining the organism's distribution in the marine environment (Karlenskint et al. 2008). There are strong gradients from north to south in surface water temperature (approx. $6-8{ }^{\circ} \mathrm{C}$ ), salinity (5-7 ppt), nutrient concentration and turbidity in the Red Sea (Gordeyeva 1970, Morcos 1970, Morley 1975, Edwards and Head 1987, Weikert 1987).

The gradient observed during this study could also be due to different types of habitat available in the different sites, as well as their different amounts of coral cover, which could produce more or less favorable conditions for the development of juvenile fishes (availability of food, food supply, substrate complexity with different coral cover, etc.). This study identified major differences in the faunal composition and relative abundance in almost all of the fish families investigated. They included the studied species of triggerfishes (Balistidae), surgeonfishes (Acanthuridae), butterflyfishes (Chaetodontidae), angelfishes (Pomacanthidae), damselfishes (Pomacentridae), Wrasses (Labridae), dottybacks (Pseudochromidae) and P. squamipinnis in the family grouperfishes (Serranidae). Similar results were obtained by (Ormond and Edwards 1987; Roberts and Ormond 1987; Roberts et al. 1992). Sheppard et al. (1992) indicated that there are marked differences among the different regions of the Red Sea in fish species richness, assemblage composition and species abundances. Brokovich et al. (2006) reported a strong correlation between fish assemblages and the different types of habitats at the northern tip of the Gulf of Aqaba. Similar results were also reported by Khalaf and Kochzius (2002).

The fish fauna of the Djiboutian coast is shared with the Indian Ocean and the Red Sea. However, in terms of species composition, the Red Sea influence dominates, especially in areas near to Bab el Mandeb (Barrat and Medeley, 1990). A biogeographic analysis of the Indian Ocean coral fauna based on presence/absence of species revealed a clear pattern of faunal relationships between the Red Sea, Southern Arabia and the Indian Ocean (Khalaf and Kochzius 2002). Habitat strongly influences which species are able to live in a particular place. There are considerable differences in reef structure and coral assemblages from north to south within the Red Sea. In the south, reef structures becomes shallow with macroalgal dominated frameworks (Yemen and Djibouti). In the far south there are few areas of hard substrata, and these are mainly coralline-algal reefs covered with dense growth of the brown algae Sargassum and Turbinaria (Khalaf, personal observation).

A review of the literature describing fish habitat correlations from various regions presents a convincing positive relationship between habitat structural complexity and 
reef fish diversity in the Caribbean (Risk 1972, Luckhurst and Luckhurst 1978) and in the Great Barrier Reef (McCormick 1994). The strength of this correlation however, may vary among reef types. Percent of live branching or massive coral, substratum diversity and complexity have several times been identified as important predictors of the diversity of reef fish assemblages (Talbot 1965, Talbot and Goldman 1972, Luckhurst and Luckhurst 1978, Bouchon-Navaro and Bouchon 1989). This study supports the above mentioned studies, and shows that a number of fish species occupy different latitudes. Species varied in their abundances from reef to reef, and adjacent reefs supported different groups of species. As a general conclusion, we suggest that differences among reefs and habitats were among important components of variability in the number of fishes and species of ornamental fishes along the Red Sea and Gulf of Aden.

The high numbers of the clownfish A. bicinctus along the Jordanian reefs at latitude $29^{\circ}$ compared to other reefs in other latitudes is perhaps due the availability of the sea anemone hosts Entacmaea quadricolor and Heteractis crispa (Huebner et al. 2012). Chadwick and Arvedlund (2005) proposed that $H$. crispa may serve as nursery habitats for A. bicinctus because they host more juvenile fish than does E. quadricolor, and Huebner et al. (2012) further documented this relationship using field experiments. The present study revealed that $A$. bicinctus, which is an endemic species to the Red Sea and Gulf of Aden, was a common and abundant species in the northern Red Sea, less common in the central Red Sea and rare or not present in the southern Red Sea and Gulf of Aden. These patterns may be due in part to the distributional and abundance patterns of the above host anemones, but detailed surveys of these anemones need to be conducted throughout the Red Sea to further test these ideas.

Two of the 3 species that belong to the family of dottybacks, Pseudochromidae i.e., P. springeri and P. fridmani were endemic to the Red Sea (Randall 1992), and both of them were not found along the Yemeni and Djiboutian reefs. The third species $P$. flavivertex which is endemic to the Red Sea and Gulf of Aden (Randall 1992) was recorded in all latitudes except at latitudes 12 and $11^{\circ}$ along the Djiboutian reefs during this investigation. A total of 14 butterflyfishes are reported from the Red Sea, of which seven are endemic or range no further than the Gulf of Aden (Randall, 1992). In the present study, 14 species of butterflyfishes have also been reported. Butterflyfish assemblages in the southern Red Sea differ from that in the north (Righton et al. 1996). Other differences occur among butterflyfish. For example, C. paucifasciatus is abundant in the Gulf of Aqaba and Gulf of Suez but absent or rare in the southern Red Sea. However, $C$. larvatus is a dominant species in the south but rare in the northern Red Sea and Gulf of Suez and absent entirely from the Gulf of Aqaba. On the other hand, there are some species such as $H$. acuminatus, $C$. melapterus and $C$. vagabundus that are present along the Djiboutian reefs but are not reported in the Red Sea. The results presented in this study demonstrate that there are many differences between the reef fish fauna of the northern and central Red Sea, from that of the southern Red Sea and Gulf of Aden. For example, P. sqamipinnis dominated fish assemblages in the northern Red Sea along the Jordanian and Egyptian coasts, whereas $C$. viridis dominated fish assemblages in the central Red Sea, along the Saudi Arabia coast at both latitudes 20 and $21^{\circ}$, and in the Gulf of Aden. 
During this survey, $C$. viridis was the most abundant species in the Red Sea and Gulf of Aden. This species dominated the reefs at latitudes 21, 20, 15, 12 and $11^{\circ}$. Similar results were reported at Nuweiba (Ben-Tuvia, 1983), at Djiboutian reefs (Barrat and Medley 1990), at Sanganeb atoll (Krupp et al. 1993), and in Eritrean reefs (Daw et al. 2001). C. viridis usually forms large aggregations and is found associated with large heads of Acropora corals that provide shelter from predators and a nocturnal retreat. Thus, these distributional patterns for this fish may indicate a higher abundance of large Acropora corals on southern than northern reefs in this region. The second most abundant species was $P$. squamipinnis, which dominates the reefs at latitudes 29, 27 and $22^{\circ}$. Similar findings were recorded at the Japanese Garden reef site at Eilat (Rilov and Benayahu 2000), at Nuweiba (Ben-Tuvia et al. 1983), at Sanganeb Atoll (Krupp et al. 1993), and on Jordanian reefs (Khalaf and Kochzius 2002). This species occurs usually in small to very large aggregations around rock or coral heads. These two species feed on plankton above rich beds of live coral (Khalaf and Disi 1997). These patterns indicate the importance of live coral cover, reef rugosity, and availability of plankton in the distribution of these reef fishes.

\section{Acknowledgments}

We would like to thank the regional Organization for the Conservation of the Environment of the Red Sea and Gulf of Aden (PERSGA) the executing Agency of the Strategic Action Programme (SAP) under which this survey was carried out. We appreciate the cooperation and help of the ornamental fish trade companies in the study area; PERSGA/SAP National Programme Coordinators in Djibouti and Yemen; Marine Science Station, Aqaba, Jordan; Fisheries Research Center of the Ministry of Agriculture and Faculty of Marine Science King Abdulaziz University, Saudi Arabia. Many thanks are due to everyone who provided assistance during the field surveys. Thanks are due the reviewer, N.E. Chadwick (Auburn University, Alabama USA), R. Manasrah, S. Al-Rousan and F. Al-Horani (The University Of Jordan-Aqaba) for improving the manuscript.

\section{References}

Ahl E (1923) Zur Kenntnis der Knochenfischfamilie Chaetodontidae insbesondere der Unterfamilie Chaetodontinae. Archiv für Naturgeschichte Berlin (N.F.) v. 89 Abt. A, Heft 5: 1-205, Pls. 1-2.

Alwany MA, Stachowitsch M (2007) Distribution and diversity of six common reef fish families along the Egyptian coast of the Red Sea. Journal of Fisheries and Aquatic Sciences, 2(1): 1-16. doi: 10.3923/jfas.2007.1.16

Barratt L, Medley P (1990) Managing multi species ornamental reef fisheries. Progress in Underwater Science, 15: 55-72. 
Bennett ET (1832) Observations on a collection of fishes from the Mauritius, presented by Mr. Telfair, with characters of new genera and species. Proceedings of the Committee of Science and Correspondence of the Zoological Society of London 1830-31 (pt 1): 165-169.

Bennett JW (1828-30) A selection from the most remarkable and interesting fishes found on the coast of Ceylon. London. First Edition: i--viii + 30 unnumbered pp., Pls. 1-30.

Ben-Tuvia A, Diamant A, Baranes A, Golani D (1983) Analysis of a coral reef fish community in shallow -waters of Nuweiba, Gulf of Aqaba, Red Sea. Bulletin of the Institute of Oceanography and Fisheries, 9: 193-206.

Bleeker P (1856) Beschrijvingen van nieuwe en weinig bekende vischsoorten van Amboina, verzameld op eene reis door den Molukschen Archipel gedaan in het gevolg van den Gouverneur Generaal Duymaer van Twist, in September en Oktober 1855. Acta Societatis Regiae Scientiarum Indo-Neêrlandicae v. 1: 1-76.

Bloch ME (1787) Naturgeschichte der ausländischen Fische. Berlin. v. 3: i-xii + 1-146, Pls. $181-216$.

Bloch ME (1795) Naturgeschichte der ausländischen Fische. Berlin. v. 9: i-ii + 1-192, Pls. 397-429.

Bloch ME, Schneider JG (1801) ME Blochii, Systema Ichthyologiae Iconibus cx Ilustratum. Post obitum auctoris opus inchoatum absolvit, correxit, interpolavit Jo. Gottlob Schneider, Saxo. Berolini. Sumtibus Auctoris Impressum et Bibliopolio Sanderiano Commissum. $\mathrm{i}-\mathrm{lx}+1-584$, Pls. $1-110$.

Blyth E (1852) Report on Ceylon mammals, birds, reptiles and fishes. In: E. F. Kelaert, Prodromus faunae Zeylanicae, being contributions to the zoology of Ceylon. Colombo, Ceylon. i-viii + 1-197 + Appendix 1-62 + 4 unnumbered page index. [New fishes on Appendix pp. 48-50.]

Boddaert P (1772) Van den Tweedornigen Klipfisch. De Chaetodonte diacantho descripto atque accuratissima icone illustrata. M. Magérus, Amsterdam. De Chaetodonte diacantho descripto. Bulletin of the Illinois State Laboratory of Natural History 1 pl.: 43 pp.

Bouchon-Navaro Y (1980) Quantitative distribution of the Chaetodontidae on a fringing reef of the Jordanian coast (Gulf of Aqaba, Red Sea). Marine Biology, 63/:79-86.

Bouchon-Navaro Y, Bouchon C (1989) Correlations between chaetodontid fishes and coral communities of the Gulf of Aqaba (Red Sea). Environmental Biology of Fishes, 25/13:47-60. doi: 10.1007/BF00002200

Bourliere F, Harmelin-Vivien ML (1989) Species diversity in tropical vertebrates: an ecosystem perspective. In Harmelin-Vivien, M. L., Bourliere. (Eds) Vertebrates in complex tropical System. Springer-Verlag, New York.

Brokovich E, Baranes A, Goren M (2006) Habitat structure determines coral reef fish assemblages at the northern tip of the Red Sea. Ecological Indictors, 6: 494-507. doi: 10.1016/j. ecolind.2005.07.002

Carter RN, Prince SP (1981) Epidemic models used to explain biogeographic distribution limits. Nature (London), 293:644-654. doi: 10.1038/293644a0

Chadwick NE, Arvedlund M (2005) Abundance of giant seaanemones and patterns of association with anemonefish in the northern Red Sea. Journal of the Marine Biological Association of the United Kingdom, 85: 1287-1292. doi: 10.1017/S0025315405012440 
Cuvier G, Valenciennes A (1829) Histoire naturelle des poissons. Tome quatrième. Livre quatrième. Des acanthoptérygiens à joue cuirassée. v. 4: i-xxvi + 2 pp. + 1-518, Pls.

Cuvier G, Valenciennes A (1830) Histoire naturelle des poissons. Tome cinquième. Livre cinquième. Des Sciénoïdes. v. 5: i-xxviii + 1-499+ 4 pp., Pls. 100-140.

Cuvier G, Valenciennes A (1831) Histoire naturelle des poissons. Tome septième. Livre septième. Des Squamipennes. Livre huitième. Des poissons à pharyngiens labyrinthiformes. F. G. Levrault, Paris. v. 7: i-xxix + 1-531, Pls. 170-208. .

Cuvier G, Valenciennes A (1839) Histoire naturelle des poissons. Tome treizième. Livre seizième. Des Labroïdes. v. 13: i-xix + 1-505 + 1 p., Pls. 369-388

Daw TM, Roger GCC, Mapson P, Kynoch JE (2001) Structure and management issue of the emerging ornamental fish trade in Eriterea. Aquarium Sciences and Conservation, 3:53-64. doi: 10.1023/A:1011321620692

Edwards AJ (2002) Report to PERSGA on workshop held at the Sub-regional Research and training center at the faculty of Marine Science of King abdul Aziz University, Jeddah from $9^{\text {th }}-15^{\text {th }}$ April 2002 with Guidelines for sampling, data collection and analysis.

Edwards AJ, Head SM (1987) Red Sea. Key Environments Series, (Eds) Pergamon Press, Oxford, $441 \mathrm{p}$

English C, Wilkinson C, Baker V (1994) Survey manual for tropical marine resources. Australian Institute of Marine Science, Townsville.

Forsskål PS (1775) Descriptiones animalium avium, amphibiorum, piscium, insectorum, vermium; quae in itinere orientali observavit... Post mortem auctoris edidit Carsten Niebuhr. Hauniae. 1-20 + i-xxxiv + 1-164.

Froese R, Pauly D (2000) FishBase 2013: Concepts, design and data sources. 344 p. ICLARM, Los Baños, Laguna, Philippines.

Golani D, Bogorodsky SV (2010) The fishes of the Red Sea-reapprasial and updated checklist. Zootaxa, 2463: 1-135.

Gordeyeva KT (1970) Quantitative distribution of zooplankton in the Red Sea. Okeanologiya, 10: $867-871$

Goren M, Dor M (1994) An update checklist of the fishes of the Red Sea. CLOFERS II. Jerusalem, $120 \mathrm{pp}$.

Guichenot A (1863) Faune ichthyologique. In: L. Maillard, Notes sur l'ile de la Réunion (Bourbon). Paris. 2nd Partie, Annexe C.: C1-C32.

Huebner LK, Dailey B, Titus BM, Khalaf M, Chadwick NE (2012) Host preference and habitat segregation among Red Sea anemonefish: Effects of seaanemone traits and fish life stage. Marine Ecology Progress Series, 464: 1-15. doi: 10.3354/meps09964

Karleskint G, Turner R, Small JW (2008) Introduction to Marine Biology. Third edition, pp. 581 Khalaf MA (2004) Fish fauna along the Jordanian Coast-Gulf of Aqaba. Journal of Faculty of Marine Science 15:23-50.

Khalaf MA, Al-Horani FA, Manasrah R, Al-Rousan SA (2006) Community structure of the family Pomacentridae along the Jordanian coast, Gulf of Aqaba, Red Sea. Zoology in the Middle East, 37: 47-62. doi: 10.1080/09397140.2006.10638148

Khalaf MA, Disi AM (1997) Fishes of the Gulf of Aqaba. Marine Science Station, No.8.pp.252. 
Khalaf MA, Kochzius M (2002) Community structure and biogeography of shore fishes in the Gulf of Aqaba, Red Sea. Helgoland Marine Research, 55:252-284. doi: 10.1007/s10152001-0090-y

Klausewitz W (1968) Fische aus dem Roten Meer. IX. Pseudochromis fridmani n. sp. aus dem Golf von Aqaba (Pisces, Osteichthyes, Pseudochromidae). Senckenbergiana Biologica v. 49 (no. 6): 443-450.

Klunzinger CB (1884) Die Fische des Rothen Meeres. I. Theil Stuttgart.

Klunzinger CB (1871) Synopsis der Fische des Rothen Meeres. II. Theil. Verhandlungen der K.-K. zoologisch-botanischen Gesellschaft in Wien v. 21: 441-688.

Krupp F, Paulus T, Nasr D (1993) Coral reef fish survey. In: Krupp F, Turkay M, El Hag AGD, Nasr D (Eds) Comparative ecological analysis of biota and habitats in littoral and shallow sublittoral waters of the Sudanese Res Sea. Project report. Forschungsinstitut Senckenberg, Frankfurt/Faculty of Marine Science and Fisheries, Port Sudan, 63-82 pp.

Lacepède BGE (1801) Histoire naturelle des poissons. v. 3: i-lxvi + 1-558, Pls. 1-34.

Letourneur Y, Labrosse P, Kulbicki M (1999) Commercial fish assemblages on New Caledonian fringing reefs submitted to different levels of ground erosion. Oceanologica Acta. 6. 22. 609-622..

Linnaeus C (1758) Systema Naturae, Ed. X. (Systema naturae per regna tria naturae, secundum classes, ordines, genera, species, cum characteribus, differentiis, synonymis, locis. Tomus I. Editio decima, reformata.) Holmiae. v. 1: i-ii + 1-824.

Lubbock R (1975) Fishes of the family Pseudochromidae (Perciformes) in the northwest Indian Ocean and Red Sea. Journal of Zoology (London) v. 176 (pt 1): 115-157, Pls. 1-3.

Luckhurst BE, Luckhurst K (1978) Analysis of the influence of the substrate variables on coral reef fish communities. Marine Biology, 49: 317-323. doi: 10.1007/BF00455026

McCormick MI (1994) Comparison of field models for measuring surface topography and their association with a tropical reef fish community. Marine Ecology Progress Series, 112: 87-96. doi: 10.3354/meps 112087

Morcos SA (1970) Physical and chemical oceanography of the Red Sea. Oceanographic and Marine Biology Annual Reviews, 8:173-202.

Morley NJF (1975) The coastal waters of the Red Sea. Bulletin of Marine Research Centre, Saudi Arabia, No. 5. pp. 8-19.

Myers RF (1991) Micronesian Reef Fishes: A practical Guide to the Identification of the Inshore Marine Fishes of the Tropical Central and Western Pacific. Coral Graphica, 298pp.USA.

Ormond RFG, Edwards AJ (1987) Red Sea Fishes. In: Red Sea, A. J. Edwards and S. M. Head, ed., Key Environments Series, Pergamon Press, Oxford, p. 251-287.

Park M (1797) Descriptions of eight new fishes from Sumatra. The Transactions of the Linnean Society of London v. 3: 33-38, Pl. [6]. doi: 10.1111/j.1096-3642.1797.tb00553.x

Peters W (CH) (1855) Übersicht der in Mossambique beobachteten Seefische. Monatsberichte der Königlichen Preuss[ischen] Akademie der Wissenschaften zu Berlin 1855: 428-466. Primer-E (2000) PRIMER 5 (Polymouth Routines in Multivariate Ecological Research). PRIMER-E, Polymouth Marine Laboratory, UK.

Randall JE (1992)'Red Sea Reef Fishes.`(IMMEL Publications: London). 
Righton D, Kemp J, Ormond R (1996) Biogeography, community structure and diversity of Red Sea and western Indian ocean butterflyfishes. Journal of Marine Biological Association UK, 76: 223-8. doi: 10.1017/S0025315400029167

Rilov G, Benyahu Y (2000) Fish assemblages on natural versus verical artificial reefs: the rehabilitation perspective. Marine Biology, 136: 931-942. doi: 10.1007/s002279900250

Risk MJ (1972) Fish diversity on a coral reef in the Virgin Island. Atoll Res. Bull, 153: 1-6. doi: $10.5479 /$ si.00775630.153.1

Roberts CM, Ormond RFG (1987) Habitat complexity and coral reef fish diversity and abundance on Red Sea fringing reefs. Marine Ecology Progress Series, 41: 1-8. doi: 10.3354/ meps041001

Roberts CM, Dawson Shepherd AR, Ormond RFG (1992) Large scale variation in assemblage structure of Red Sea butterflyfishes and angelfishes. Journal of Biogeography, 19: 239-250. doi: $10.2307 / 2845449$

Roux-Estève R, Fourmanoir P (1955) Poissons capturés par la mission de la "Calypso» en Mer Rouge. Annales de l'Institut Oceanographique Monaco (New Series) v. 30 (art. 7): 195-203.

Rüppell WPES (1828-30) Atlas zu der Reise im nördlichen Afrika. Fische des Rothen Meers. Frankfurt am Main (Heinrich Ludwig Brönner). 1-141 + 3 pp., Pls. 1-35.

Rüppell WPES (1835-38) Neue Wirbelthiere zu der Fauna von Abyssinien gehörig. Fische des Rothen Meeres. Siegmund Schmerber, Frankfurt am Main. i-ii + 1-148, Pls. 1-33. [1835:1-28, Pls. 1-7; 1836:29-52, Pls. 8-14; 1837:53-80, Pls. 15-21; 1838:81-148, Pls. 22-33.].

Sheppard C, Price A, Roberts C (1992) Marine Ecology of the Arabian Region. Academic Press, San Diego, California, 358 p.

Smith MM, Heemstra PC (Eds) (1986) Smiths' sea fishes. Berlin; Springer-verlag. doi: 10.1007/978-3-642-82858-4

Sokal RR, Rohlf FJ (1981) Biometry. W. H. Freeman and Company, San Francisco, California, $859 \mathrm{p}$.

Steindachner F (1893) Ichthyologische Beiträge (XVI). Anzeiger der Akademie der Wissenschaften in Wien v. 30 (no. 14): 150-152.

Talbot FH (1965) A description of coral structure of Tutia reef (Tanganyika Territory, East Africa) and its fish fauna. Proc Zool Soc London, 145: 431-471. doi: 10.1111/j.14697998.1965.tb02026.x

Talbot FH, Goldman B (1972) A preliminary report on the diversity and feeding relationships of reef fishes in One-Tree Island, Great Barrier Reef systems. Pro. $1^{\text {st }}$ Int. Coral Reef Symp, 1969: 425-443.

Thompson AA Mapstone BD (1997) Observer effects and training in underwater visual surveys of reef fishes. Marine Ecology Progress Series, 154: 53-63. doi: 10.3354/meps154053

UNEP Regional seas report and studies (1997) Assessment of land-based sources and activities affecting the marine environment in the Red Sea and Gulf of Aden, pp 67.

Weikert H (1987) Plankton and the pelagic environment. In: Red Sea, Edwards AJ and Head SM (Eds). Key Environments Series, Pergamon Press, Oxford, p. 90-111. 